\title{
Chloramphenicol Derivatives with Antibacterial Activity Identified by Functional Metagenomics
}

\author{
Shamima Nasrin, ${ }^{\dagger, \#}$ Suresh Ganji, ${ }^{\ddagger}, \#$ Kavita S. Kakirde, ${ }^{\dagger}$ Melissa R. Jacob, ${ }^{\ddagger}$ Mei Wang, ${ }^{\ddagger 0}$ \\ Ranga Rao Ravu, ${ }^{\ddagger}$ Paul A. Cobine, ${ }^{\dagger}$ Ikhlas A. Khan, ${ }^{\ddagger},{ }^{\prime}$ Cheng-Cang Wu, ${ }^{\perp}$ David A. Mead,, \\ Xing-Cong Li, $*, *, \$$ and Mark R. Liles ${ }^{*, t, \| \odot}$ \\ ${ }^{\dagger}$ Department of Biological Sciences, Auburn University, Auburn, Alabama 36849, United States \\ ${ }^{\ddagger}$ National Center for Natural Products Research, Research Institute of Pharmaceutical Sciences, School of Pharmacy, The University \\ of Mississippi, University, Mississippi 38677, United States \\ ${ }^{\S}$ Department of Biomolecular Sciences, School of Pharmacy, The University of Mississippi, University, Mississippi 38677, United \\ States \\ ${ }^{\perp}$ Lucigen Corporation, Middleton, Wisconsin 53562, United States \\ "Varigen Biosciences Corporation, Madison, Wisconsin 53719, United States
}

\begin{abstract}
A functional metagenomic approach identified novel and diverse soil-derived DNAs encoding inhibitors to methicillinresistant Staphylococcus aureus (MRSA). A metagenomic DNA soil library containing 19200 recombinant Escherichia coli BAC clones with $100 \mathrm{~Kb}$ average insert size was screened for antibiotic activity. Twenty-seven clones inhibited MRSA, seven of which were found by LC-MS to possess modified chloramphenicol $(\mathrm{Cm})$ derivatives, including three new compounds whose structures were established as 1-acetyl-3-propanoylchloramphenicol, 1-acetyl-3-butanoylchloramphenicol, and 3-butanoyl-1-propanoylchloramphenicol. Cm was used as the selectable antibiotic for cloning, suggesting that heterologously expressed enzymes resulted in derivatization of $\mathrm{Cm}$ into new chemical entities with biological activity. An esterase was found to be responsible for the enzymatic regeneration of $\mathrm{Cm}$, and the gene $\operatorname{trf} A$ responsible for plasmid copy induction was found to be responsible for inducing antibacterial activity in some clones. Six additional acylchloramphenicols were synthesized for structure and antibacterial activity relationship studies, with 1-p-nitrobenzoylchloramphenicol the most active against Mycobacterium intracellulare and Mycobacterium tuberculosis, with MICs of 12.5 and $50.0 \mu \mathrm{g} / \mathrm{mL}$, respectively.
\end{abstract}

$\mathrm{T}$ he need for novel antimicrobial compounds is increasing with the emergence of hypervirulent and multidrugresistant (MDR) bacterial pathogens, such as MRSA. ${ }^{1,2}$ The increasing frequency of antimicrobial resistance observed among Staphylococcus aureus clinical isolates and their ability to produce biofilms in tissues and medical devices limit treatment options. ${ }^{3}$ The glycopeptide antibiotic vancomycin is the first choice of drug for the treatment of methicillin-resistant S. aureus (MRSA) infections; however, its application is limited by the emergence of strains with reduced antimicrobial susceptibility ${ }^{4}$ and the occurrence of vancomycin treatment failure and mortality in patients with $S$. aureus bacteremia., Several new alternative antibiotics such as daptomycin, linezolid, and tigecycline are used to treat MRSA-infected patients. ${ }^{7}$ However, their application efficacies are limited by the different varieties of infection caused by MRSA. ${ }^{8}$ The three newest drugs oritavancin, dalbavancin, and tedizolid have recently been approved by the FDA for treating MRSA infections, ${ }^{9}$ yet these new drugs can only be used for skin infection and nosocomial pneumonia. There is therefore a need to discover novel antimicrobial compounds to combat MRSA and other MDR pathogens. ${ }^{1,2}$

Functional metagenomics has opened a new avenue for natural products drug discovery. ${ }^{10-12}$ By sampling DNA directly from a natural environment it is possible to access a greater proportion of microbial genomes ${ }^{13,14}$ and screen the resultant metagenomic libraries for recombinant clones that express a specific activity. Fosmid-based metagenomic approaches ${ }^{15}$ have been used in other studies to identify novel small molecules with antimicrobial properties, ${ }^{16}$ such as the isolation of terragine $\mathrm{E}$ and related compounds, ${ }^{17}$ longchain $N$-acyl antibiotics, ${ }^{18}$ and the antibiotic palmitoylputrescine. ${ }^{19}$ Screening larger-insert metagenomic libraries for antimicrobial activity is advantageous due to the higher probability that a recombinant clone will encode an intact biosynthetic gene cluster or antimicrobial peptides. In this study, we screened a soil metagenomic library containing 110 
$\mathrm{Kb}$ average size inserts constructed in a copy-inducible BAC vector $^{17,20}$ for recombinant clones that inhibited MRSA metabolic activity. We identified seven metagenomic clones that were capable of modifying chloramphenicol $(\mathrm{Cm})$ to biologically active $\mathrm{Cm}$ derivatives. The structures of the three new $\mathrm{Cm}$ derivatives were determined, and these compounds were found to have antibacterial activity against MRSA, Mycobacterium intracellulare, and M. tuberculosis. These findings demonstrate that large-insert soil metagenomic libraries can be functionally screened to access previously undescribed environmental DNA and explore their biochemical diversity for antibacterial discovery.

\section{RESULTS AND DISCUSSION}

The metagenomic library used in this study was obtained using randomly sheared metagenomic DNA that resulted in large insert sizes that increased the number of genes per each clone. An in situ lysis method was developed for high-throughput library screening for clones expressing an antibacterial activity that allowed for growth of the metagenomic cultures, lysis, and screening in the same 96-well plates and detected both extraand intracellular compounds. An inducible copy number BAC vector was used to enhance natural product expression. The identified clones with antibacterial activity were analyzed in terms of biosynthetic gene clusters, active metabolites, and relevant genes and enzymes associated with the activity.

Identification of Antibiotic-Producing Clones. To enhance expression of the cloned genes, cultures were incubated for a prolonged time in stationary phase. ${ }^{21,22}$ Each E. coli clone was grown for $48 \mathrm{~h}$ at $37^{\circ} \mathrm{C}$, and cells were lysed by freezing at $-80{ }^{\circ} \mathrm{C}$ followed by rapid thawing at $55^{\circ} \mathrm{C}$, prior to assaying supernatants for inhibition of MRSA metabolic activity. The addition of nalidixic acid along with the diluted log-phase MRSA inhibited E. coli growth but did not interfere with MRSA growth. The use of the metabolic indicator dye resazurin allowed visualization of the wells in which MRSA cells were metabolically active and induced a color change from blue to pink as well as the generation of fluorescence. A total of 136 metagenomic clones that resulted in at least a $20 \%$ reduction in fluorescence compared to an empty vector control were selected for subsequent validation. The 136 clones identified from the primary screen out of 19200 clones in the library reflects a hit rate of $0.7 \%$.

Validation of Recombinant Clones with Antimicrobial Activity. Clones that were only weakly positive compared to the empty vector negative control and/or did not show consistent activity were eliminated, as well as clones that were potential cross-well contamination, resulting in 27 candidates selected for additional biochemical and genetic characterization.

Retransformation of Antibiotic-Producing Clones. The 27 clones that expressed an antibacterial activity were subjected to a restriction fragment length analysis using pulsed field gel electrophoresis (PFGE), and each had large and unique DNA inserts (Figure S1). Each clone's DNA was used to transform a naive E. coli, and the resulting recombinants all showed significant anti-MRSA activity when assayed with MRSA EAMC30 (Table S1). These experiments indicated that the cloned DNA was necessary and sufficient to confer bioactivity on the E. coli heterologous host for all 27 of the positive hits that were validated.

Effect of Arabinose Induction on Antibiotic Activity. The copy-control BAC vector used for this library can be amplified from single copy up to $\sim 50$ copies per $E$. coli cell by the addition of arabinose to the growth medium. ${ }^{23}$ Enhanced expression of cloned genes due to gene dosage amplification may increase downstream concentrations of antibiotic products, and therefore the likelihood of their detection. This effect was observed when representative clones with the highest activity (P11K11, P15G24, P16O8, P17L5, P29A3, P30A5, and P30L8) were grown with and without $0.01 \%$ arabinose, with arabinose addition showing increased antibiotic activity ranging from 3.5to 13.2-fold relative to the clone cultures without arabinose (Figure S2).

Preliminary Characterization of Antibiotic-Expressing Clones. The MRSA strain EAMC30 inhibition activity for each clone or clone fraction was calculated as the \% reduction of resazurin fluorescence as compared to the respective negative control. For the negative control, both the cell-free supernatant and the cell lysate were tested so that a true comparison could be made with the respective clone samples. MRSA inhibition ranged from $8 \%$ to $75 \%$ (Table S1) among the 27 validated clones tested. Seventeen clones showed cell-free supernatant inhibition activity equivalent to that of their cognate cell lysates (Table S1). This suggests that the active compound(s) is most likely extracellular or readily secreted out of the cell. For 10 clones the activity in the cell lysate was significantly higher than the activity detected in the cell-free supernatant. This presumably indicates that the active compound(s) is intracellular or membrane-associated, is not readily secreted out of the cell, and/or is freely soluble in the supernatant. For all of the subsequent tests for these 10 clones with higher activity in the cell lysate, the cell lysate was used in bioassays, whereas the cell-free supernatant was used for the other clones.

Cell-free supernatants or lysates that were incubated for 10 min in a boiling water bath resulted in up to $91 \%$ inhibition activity against MRSA strain EAMC30 (Table S1), with four clones showing complete loss of activity, suggesting that the active compound(s) is heat sensitive. Seven clones showed partial loss in activity, while 16 clones showed a gain in activity, indicating that the active compound(s) is heat stable and likely to be nonproteinaceous. Twelve clones showed a 5-12-fold increase in inhibitory activity after boiling, perhaps because the active compounds are sequestered in some way in the crude lysate.

In the fractionation assay, the filtrate obtained after separation using a $3 \mathrm{kDa}$ molecular weight cutoff (MWCO) membrane was tested. For 11 of the 27 clones the filtrate $(<3$ $\mathrm{kDa}$ fraction) did not show a loss of activity. For 14 clones, even though there was a decrease in the \% activity the overall MRSA inhibition was still more than $50 \%$. For seven clones, there was a significant drop in the activity with less than $50 \%$ inhibition. Taken together, these data indicated that for many of the clones the activity was attributable to a heat-resistant nonproteinaceous small-molecule compound with molecular weight less than $3 \mathrm{kDa}$.

Sequence Analysis of Anti-MRSA Clone Inserts. DNA insert sequences were obtained for all 27 clones using barcoded next-generation sequencing. After reads were trimmed the sequences were used for assembly de novo. Most of the clones contained large inserts with more than 100 predicted open reading frames (ORFs) (Supplemental Data 1). Based on an analysis of the nearest relatives to the top BLAST hit for the majority of ORFs in each respective clone, the distribution of clone origins at a phylum level was 37\% Proteobacteria, 33\% Acidobacteria, 7\% Planctomycetes, 7\% Bacteriodetes, and 4\% Gemmatimonadetes and Firmicutes each (Supplementary Data 
1). Analysis of clone insert DNAs using antiSMASH4.0 predicted that eight clones (P5C24, P22C4, P23K15, P27M10, P28H1, P28I7, P37O10, and P46O24) encode biosynthetic gene clusters. Among these eight clones, five clones (P5C24, P22C4, P23K15, P27M10, and P28I7) were predicted to contain a cluster, but in each clone less than $10 \%$ of the genes in the putative cluster had a significant ClusterBlast hit. The other three clones were predicted to contain a biosynthetic gene cluster with significant homology to a known cluster. The clone $\mathrm{P} 28 \mathrm{H} 1$ was predicted to encode a $30.5 \mathrm{~Kb}$ gene cluster with limited homology (at most 13\% of genes were similar) to a fatty acid-ladderane biosynthetic cluster (Supplemental Data 1). While the predicted core biosynthetic genes had closest GenBank matches to hypothetical proteins identified in Armatimonadetes taxa (range of 45-54\% similarity), other predicted ORFs on this clone had relatively low $\%$ similarities and diverse putative origins (including from the phyla Acidobacteria, Firmicutes, and Proteobacteria), leaving the encoded functions and origin of this cloned DNA in doubt. The clone $\mathrm{P} 37 \mathrm{O} 10$ was predicted to encode four ORFs required for biosynthesis of a bacteriocin (Supplemental Data 1), and all four ORFs had a top BLAST match as a gene product from Paracoccus denitrificans (range of 61-68\% similarity). While to our knowledge no bacteriocins have been reported from a Paracoccus spp., the related bacterium Rhodobacter capsulatus has been reported to produce bacteriocins; ${ }^{24}$ however, given the phylogenetic distance between Paracoccus spp. and S. aureus and the identification of $\mathrm{Cm}$ derivatives from clone $\mathrm{P} 37 \mathrm{O} 10$ supernatants (Figure 1), it is unlikely that this predicted cluster is involved in the observed anti-MRSA activity. The clone $\mathrm{P} 46 \mathrm{O} 24$ was predicted to contain a biosynthetic gene cluster $\sim 77.4 \mathrm{~Kb}$ in size that encodes a resorcinol-arylpolyene-like cluster, with $88 \%$ of the genes showing similarity to the flexirubin cluster from Chitinophaga pinensis (Supplemental Data 1), ${ }^{25}$ which is responsible for biosynthesis of orange flexirubin pigments that are characteristic of many bacteria within the Bacteriodetes phylum. ${ }^{26}$ Like the flexirubin cluster, clone $\mathrm{P} 46 \mathrm{O} 24$ was predicted to contain several $\beta$-ketoacyl synthases that suggests a type II fatty acid-like synthesis of the polyene component; ${ }^{25}$ however, no pigmentation was observed for E. coli containing clone $\mathrm{P} 46 \mathrm{O} 24$, and to our knowledge no antibacterial activity has been associated with flexirubin pigments.

In the case of clone P6L4, in silico analysis indicated the presence of three ORFs predicted to encode esterase-like gene products, which were subcloned by targeted PCR and cloning. In contrast, with the seven clones that expressed a $\mathrm{Cm}$ derivative (see sections below), sequence analysis did not indicate any obvious candidates (e.g., gene products that would catalyze $\mathrm{Cm}$ acetyl-, propanol-, or butanolation). Since these clones contained many predicted ORFs with no significant BLAST hit or ORFs with a significant hit annotated as a hypothetical protein of unknown function, a random subcloning approach was adopted in order to identify gene products contributing to $\mathrm{Cm}$ derivative formation. At least 96 subclones derived from each clone were tested for anti-MRSA activity, but only two of the seven clones (P6B5 and P35B14, see below) were found to have subclones that expressed antiMRSA activity. It is possible that $\mathrm{Cm}$ derivative formation in the other five clones required additional genetic loci that were not captured on the $4-8 \mathrm{~Kb}$ subcloned fragments or that differences in plasmid copy number or other regulatory factors affected gene expression.

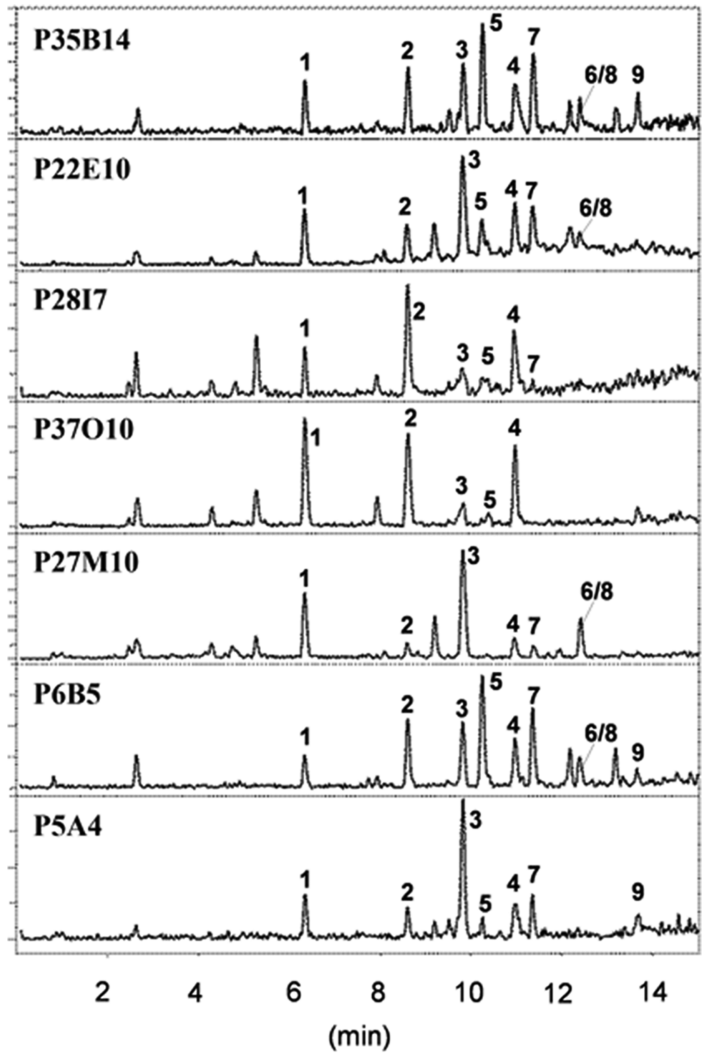<smiles>[R20]CC(NC(=O)C(Cl)Cl)C(O)(O[R20])c1ccc([N+](=O)[O-])cc1</smiles>

$\begin{array}{lll} & \mathrm{R}_{1} & \mathrm{R}_{2} \\ \mathbf{1} & \mathrm{H} & \mathrm{H} \\ \mathbf{2} & \mathrm{H} & \mathrm{COCH}_{3} \\ \mathbf{3} & \mathrm{H} & \mathrm{COCH}_{2} \mathrm{CH}_{3} \\ \mathbf{4} & \mathrm{H} & \mathrm{COCH}_{2} \mathrm{CH}_{2} \mathrm{CH}_{3} \\ \mathbf{5} & \mathrm{COCH}_{3} & \mathrm{COCH}_{3} \\ \mathbf{6} & \mathrm{COCH}_{2} \mathrm{CH}_{3} & \mathrm{COCH}_{2} \mathrm{CH}_{3} \\ \mathbf{7} & \mathrm{COCH}_{3} & \mathrm{COCH}_{2} \mathrm{CH}_{3} \\ \mathbf{8} & \mathrm{COCH}_{3} & \mathrm{COCH}_{2} \mathrm{CH}_{2} \mathrm{CH}_{3} \\ \mathbf{9} & \mathrm{COCH}_{2} \mathrm{CH}_{3} & \mathrm{COCH}_{2} \mathrm{CH}_{2} \mathrm{CH}_{3}\end{array}$

Figure 1. LC-MS chromatograms of seven metagenomic clones showing $\mathrm{Cm}$ (1) and its derivatives (2-9). HPLC conditions: Acquity UPLC BEH C $\mathrm{C}_{18}$ column $(2.1 \times 150 \mathrm{~mm}, 1.7 \mu \mathrm{m})$; gradient elution from $10 \%$ to $100 \% \mathrm{CH}_{3} \mathrm{CN}$ in $\mathrm{H}_{2} \mathrm{O}$.

Characterization of $\mathrm{Cm}$ Derivatives from Metagenomic Clones. For the majority of clones that expressed an antiMRSA activity, no unique metabolite was observed by LC-MS analysis of $E$. coli cultures in comparison with E. coli containing the empty pSmartBAC-S vector (data not shown). LC-MS analysis revealed that seven metagenomic clones (P35B14, P22E10, P28I7, P37O10, P27M10, P6B5, and P5A4) active against MRSA had similar metabolic profiles (Figure 1). Cm (1) was identified in all seven clones with a retention time $\left(t_{\mathrm{R}}\right)$ of $6.37 \mathrm{~min}$ that produced typical pseudomolecular ion peaks at $\mathrm{m} / \mathrm{z} 321.2$ and 323.2 in a ratio of 5:3 in the negative ESIMS spectra. Similar isotopic patterns and UV spectra were observed for several compounds with longer $t_{\mathrm{R}}$ (e.g., compounds 2-9 in 
clone P35B14), indicating they were chlorine-containing $\mathrm{Cm}$ derivatives. These compounds gave pseudomolecular ion peaks at $\mathrm{m} / \mathrm{z} 363.2 / 365.2,377.2 / 379.2,391.2 / 393.2,405.2 / 405.2$, $419.2 / 421.2,433.2 / 435.2$, and $447.4 / 449.4$ in the negative ESIMS spectra, with a difference of 14 corresponding to the mass of a methylene group $\left(\mathrm{CH}_{2}\right)$. Although $\mathrm{Cm}$ derivatives have been reported, ${ }^{27-30}$ analogues producing some of these molecular ions were not present in current literature reports. Thus, clone P35B14 was selected for a scale-up of fermentation and chemical isolation due to the presence of typical $\mathrm{Cm}$ derivatives (Figure 1).

An ethyl acetate extract of the P35B14 clone fermentation broth was subjected to column chromatography on normalphase and reversed-phase silica gel to yield compounds 2-9, along with $\mathrm{Cm}$ (1). Compounds 2-6 were identified as 3acetylchoramphenicol, ${ }^{29}$ 3-propanoylchloramphenicol, ${ }^{29} 3$ butanoylchloramphenicol, ${ }^{31}$ 1,3-diacetylchloramphenicol, ${ }^{29}$ and 1,3-dipropanoylchloramphenicol, ${ }^{29}$ respectively, by comparison of their ${ }^{1} \mathrm{H}$ and ${ }^{13} \mathrm{C}$ NMR data and optical rotations with those reported in the literature. The structures of the new compounds 7-9 were established as follows.

Compound 7 was isolated as a colorless oil and corresponded to the peak at $t_{\mathrm{R}} 11.39 \mathrm{~min}$ in the LC-MS chromatograms (Figure 1) and the pseudomolecular ions at $\mathrm{m} /$ $z 419.2 / 421.2$ in the ESIMS spectrum. The high-resolution ESIMS (negative mode) gave, in conjunction with its ${ }^{13} \mathrm{C}$ NMR data, the molecular formula $\mathrm{C}_{16} \mathrm{H}_{18} \mathrm{~N}_{2} \mathrm{Cl}_{2} \mathrm{O}_{7}$. Comparison of the ${ }^{1} \mathrm{H}$ and ${ }^{13} \mathrm{C}$ NMR data of 7 with those of 5 and $\mathbf{6}$ indicated that it was a 1,3-diacylchloramphenicol. It was evident that one acetyl group at $\delta_{\mathrm{H}} 2.18\left(3 \mathrm{H}, \mathrm{s}, \mathrm{COCH}_{3}\right) / \delta_{\mathrm{C}} 20.8\left(\mathrm{COCH}_{3}\right)$ and $169.4\left(\mathrm{COCH}_{3}\right)$ was present in the molecule. The presence of one propanoyl group at $\delta_{\mathrm{H}} 1.15(3 \mathrm{H}, \mathrm{t}, J=7.8$ $\left.\mathrm{Hz}, \mathrm{COCH}_{2} \mathrm{CH}_{3}\right)$ and $2.37\left(2 \mathrm{H}, \mathrm{q}, J=7.8 \mathrm{~Hz}, \mathrm{COCH}_{2} \mathrm{CH}_{3}\right) /$ $\delta_{\mathrm{C}} 173.6\left(\mathrm{COCH}_{2} \mathrm{CH}_{3}\right), 27.3\left(\mathrm{COCH}_{2} \mathrm{CH}_{3}\right)$, and 9.0 $\left(\mathrm{COCH}_{2} \mathrm{CH}_{3}\right)$ was also established by $2 \mathrm{D}$ NMR COSY, HSQC, and HMBC correlations (Figure 2). Since H-1 at $\delta 6.06$

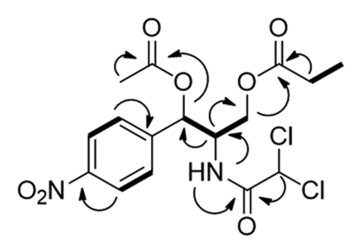

7

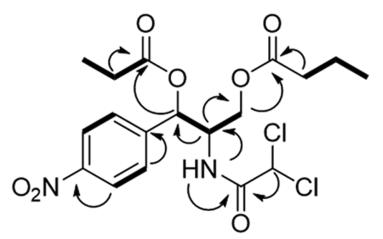

9

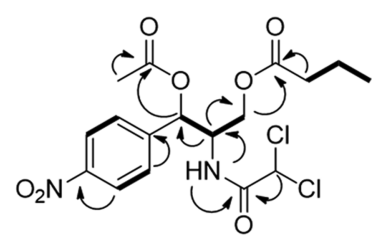

8

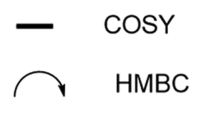

Figure 2. 2D NMR correlations of compounds 7-9.

$(1 \mathrm{H}, \mathrm{d}, J=6.3 \mathrm{~Hz})$ showed HMBC correlations with the carbonyl carbon of the acetyl group as well as C-2 ( $\delta 52.8), \mathrm{C}-3$ $(\delta$ 66.0), and the aromatic C-1' $(\delta$ 143.3), the acetyl group should be attached to the C-1 hydroxy group of the $\mathrm{Cm}$ skeleton. The linkage of the propanoyl group to the C-3 hydroxy group was confirmed by the HMBC correlations of $\mathrm{H}$ 3 at $\delta 4.20(\mathrm{dd}, J=11.7,5.5 \mathrm{~Hz})$ and $4.06(\mathrm{dd}, J=11.7,6.3 \mathrm{~Hz})$ with the carbonyl carbon at $\delta$ 173.6. Therefore, the structure of 7 was determined as 1-acetyl-3-propanoylchloramphenicol.

Compound 8 was also isolated as a colorless oil and showed close similarities to compound 7 in terms of ${ }^{1} \mathrm{H}$ and ${ }^{13} \mathrm{C}$ NMR spectra. Its HRESIMS indicated a molecular formula of $\mathrm{C}_{17} \mathrm{H}_{20} \mathrm{~N}_{2} \mathrm{Cl}_{2} \mathrm{O}_{7}$, which was one $\mathrm{CH}_{2}$ more than compound 7. The ${ }^{1} \mathrm{H}$ and ${ }^{13} \mathrm{C}$ NMR data suggested that 8 had one acetyl group and one butanoyl group in the molecule (Table 1). The key was to determine the linkage positions of the two acyl groups to the 1,3-dihydroxy groups of the $\mathrm{Cm}$ skeleton, which was achieved by the $\mathrm{HMBC}$ correlation of $\mathrm{H}-1$ at $\delta 6.06(1 \mathrm{H}, \mathrm{d}$, $J=6.3 \mathrm{~Hz}$ ) with the acetyl carbonyl C-1" at $\delta 169.5$ (Figure 2). In addition, the two methylene protons of $\mathrm{H}-3$ at $\delta 4.20$ (dd, $J$ $=11.7,5.5 \mathrm{~Hz})$ and $4.05(\mathrm{dd}, J=11.7,6.3 \mathrm{~Hz}$ ) showed HMBC correlations with the butanoyl carbonyl C-1"' at $\delta$ 173.3. Therefore, the structure of $\mathbf{8}$ was determined as 1-acetyl-3butanoylchloramphenicol.

Compound 9 had the least polarity among the eight compounds produced by this metagenomic clone. Its molecular formula was determined as $\mathrm{C}_{18} \mathrm{H}_{22} \mathrm{~N}_{2} \mathrm{Cl}_{2} \mathrm{O}_{7}$ by the HRESIMS and ${ }^{13} \mathrm{C}$ NMR spectra, which was one more $\mathrm{CH}_{2}$ than compound 8. The ${ }^{1} \mathrm{H}$ NMR data of 9 were more similar to those of 1,3-dipropanoylchloramphenicol (6), and careful analysis of the ${ }^{1} \mathrm{H}$ NMR data concluded that a propanoyl and a butanoyl group were present in the molecule. However, the minute quantity of 9 obtained from the isolation prevented acquisition of reasonable ${ }^{13} \mathrm{C}$ NMR and $2 \mathrm{D}$ NMR spectra to determine the linkage positions of the two acyl groups to the $\mathrm{Cm}$ skeleton. Two regioisomers, 3-butanoyl-1-propanoylchloramphenicol (11) and 1-butanoyl-3-propanoylchloramphenicol (12), were thus synthesized for structure elucidation (see Scheme 1 and the Experimental Section for details). Comparison of the ${ }^{1} \mathrm{H}$ NMR spectrum of 9 with those of the two regioisomers indicated that it should possess the same structure as 11. The differences in the ${ }^{1} \mathrm{H}$ NMR spectra between 11 and 12 were in the range of $\delta 2.3-2.5$ due to the two methylene protons near the carbonyl groups in the two acyl side chains (see their ${ }^{1} \mathrm{H}$ NMR spectra in the Supporting Information). In addition, acquisition and analysis of the ${ }^{13} \mathrm{C}$ NMR and 2D NMR spectra of $\mathbf{1 1}$ allowed unequivocal assignment of the ${ }^{1} \mathrm{H}$ and ${ }^{13} \mathrm{C}$ NMR resonances for this compound, including the two acyl carbonyl carbons with close chemical shifts at $\delta 173.1$ and 173.2 assigned to C- $1^{\prime \prime \prime}$ and C-1", respectively (Table 1, Figure 2 ).

The available purified natural and synthetic $\mathrm{Cm}$ derivatives as reference compounds for LC-MS analysis allowed unequivocal chromatographic assignments of compounds 1-9 in the seven metagenomic clones (Figure 1). Monoacylated compounds 24 were major metabolites present in all seven clones, while diacylated compounds 5-9 were expressed from clones P35B14 and P6B5 that showed similar metabolic profiles. It was noted that compounds 6 and 8 coeluted at $12.40 \mathrm{~min}$. Compound 9 (as a minor metabolite) was present only in clones P35B14, P6B5, and P5A4 and coeluted with an unidentified compound at $t_{\mathrm{R}} 13.19 \mathrm{~min}$. The above analyses suggest that all seven metagenomic clones contain highly active acyltransferases that are able to acylate $\mathrm{Cm}$. It should be pointed out that intramolecular rearrangement of acyl groups involved in the mono- and diacylated product generation may occur during biosynthesis ${ }^{32}$ or chemical extraction and isolation. ${ }^{33}$ However, the lack of corresponding rearranged compounds for 1-acyl $\mathrm{Cm}$ derivatives 1-3 and 1,3-diacyl $\mathrm{Cm}$ derivatives 7-9 in the LC-MS profiles suggests that all these 
Table 1. NMR Spectroscopic Data (400 $\mathrm{MHz}, \mathrm{CDCl}_{3}$ ) for Compounds 7-9 and 11

\begin{tabular}{|c|c|c|c|c|c|c|}
\hline \multirow[b]{2}{*}{ position } & \multicolumn{2}{|c|}{7} & \multicolumn{2}{|c|}{8} & \multicolumn{2}{|c|}{$9 / 11^{a}$} \\
\hline & $\delta_{\mathrm{C}}$, type & $\delta_{\mathrm{H}}(J$ in $\mathrm{Hz})$ & $\delta_{\mathrm{C}}$, type & $\delta_{\mathrm{H}}(\mathrm{J}$ in $\mathrm{Hz})$ & $\delta_{\mathrm{C}}$, type & $\delta_{\mathrm{H}}(\mathrm{J}$ in $\mathrm{Hz})$ \\
\hline 1 & 72.7, $\mathrm{CH}$ & $6.06, \mathrm{~d}(6.3)$ & 72.7 & $6.06, \mathrm{~d}(6.3)$ & 72.7 & $6.08, \mathrm{~d}(6.3)$ \\
\hline 2 & $52.8, \mathrm{CH}$ & $4.62, \mathrm{~m}$ & 52.8 & $4.61, \mathrm{~m}$ & 53.0 & $4.62, \mathrm{~m}$ \\
\hline \multirow[t]{2}{*}{3} & 66.0, $\mathrm{CH}_{2}$ & $4.20, \mathrm{dd}(11.7,5.5)$ & 66.0 & $4.20, \mathrm{dd}(11.7,5.5)$ & 66.1 & 4.20 , dd $(11.7,4.7)$ \\
\hline & & $4.06, \mathrm{dd}(11.7,6.3)$ & & 4.05 , dd $(11.7,6.3)$ & & 4.05 , dd $(11.7,6.3)$ \\
\hline $1^{\prime}$ & 143.3, C & & 143.3 & & 143.6 & \\
\hline $2^{\prime}$ & 127.6, CH & $7.52, \mathrm{~d}(8.6)$ & 127.6 & $7.52, \mathrm{~d}(8.6)$ & 127.7 & $7.53, \mathrm{~d}(8.6)$ \\
\hline $3^{\prime}$ & 124.0, $\mathrm{CH}$ & $8.21, \mathrm{~d}(8.6)$ & 124.0 & $8.23, \mathrm{~d}(9.4)$ & 124.1 & $8.24, \mathrm{~d}(8.6)$ \\
\hline $4^{\prime}$ & 148.1, C & & 148.0 & & 148.1 & \\
\hline $5^{\prime}$ & 124.0, $\mathrm{CH}$ & $8.21, \mathrm{~d}(8.6)$ & 124.0 & $8.23, \mathrm{~d}(9.4)$ & 124.1 & $8.24, \mathrm{~d}(8.6)$ \\
\hline $6^{\prime}$ & 127.6, $\mathrm{CH}$ & $7.52, \mathrm{~d}(8.6)$ & 127.6 & $7.52(\mathrm{~d}, 8.6)$ & 127.7 & $7.53, \mathrm{~d}(8.6)$ \\
\hline$-\mathrm{NH}$ & & $6.76, \mathrm{~d}(9.4)$ & & $6.74(\mathrm{~d}, 9.4)$ & & $6.78, \mathrm{~d}(9.4)$ \\
\hline$-\mathrm{CONH}$ & 164.1, C & & 164.1 & & 164.2 & \\
\hline$-\mathrm{CHCl}_{2}$ & $62.0, \mathrm{CH}$ & $5.85, \mathrm{~s}$ & 61.9 & $5.85, \mathrm{~s}$ & 62.1 & $5.86, \mathrm{~s}$ \\
\hline $1^{\prime \prime}$ & $169.4, \mathrm{C}$ & & 169.5 & & 173.2, C & \\
\hline $2^{\prime \prime}$ & $20.8, \mathrm{CH}_{3}$ & $2.18, \mathrm{~s}$ & 20.8 & $2.18, \mathrm{~s}$ & 27.6, $\mathrm{CH}_{2}$ & 2.47, qd $(7.8,3.1)$ \\
\hline $3^{\prime \prime}$ & & & & & 9.0, $\mathrm{CH}_{3}$ & $1.17, \mathrm{t}(7.8)$ \\
\hline $1^{\prime \prime \prime}$ & 173.6, C & & 173.3, C & & 173.1, C & \\
\hline $2^{\prime \prime \prime}$ & 27.3, $\mathrm{CH}_{2}$ & 2.37, q (7.8) & $35.8, \mathrm{CH}_{2}$ & $2.33, \mathrm{t}(7.8)$ & 35.9, $\mathrm{CH}_{2}$ & $2.34, \mathrm{t}(7.1)$ \\
\hline $3^{\prime \prime \prime}$ & 9.0, $\mathrm{CH}_{3}$ & $1.15, \mathrm{t}(7.8)$ & 18.3, $\mathrm{CH}_{2}$ & $1.65, \mathrm{~m}$ & 18.4, $\mathrm{CH}_{2}$ & $1.65, \mathrm{~m}$ \\
\hline $4^{\prime \prime \prime}$ & & & 13.6, $\mathrm{CH}_{3}$ & $0.96, \mathrm{t}(7.8)$ & $13.8, \mathrm{CH}_{3}$ & $0.96, \mathrm{t}(7.1)$ \\
\hline
\end{tabular}

Scheme 1. Synthesis of Regioisomers 11 and 12

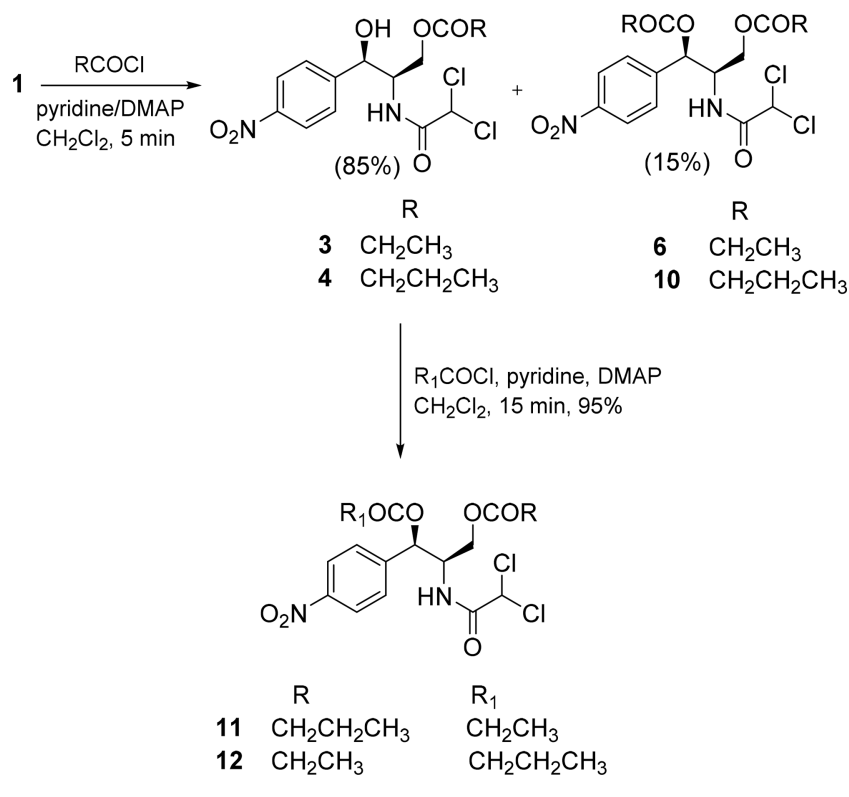

$\mathrm{Cm}$ derivatives are natural products biosynthesized by the clones.

Acylation of $\mathrm{Cm}$ is well known by $E$. coli ${ }^{34}$ and Streptomyces spp. $^{16,28}$ and has previously demonstrated to be associated with drug resistance. This is consistent with biological testing in which the isolated acylchloramphenicols $(2-7)$ and the three synthetic analogues (10-12) were inactive at $200 \mu \mathrm{g} / \mathrm{mL}$ against MRSA (strain ATCC 1708), E. coli, and Pseudomonas aeruginosa. In contrast, the $S$. aureus EAMC30 strain used in the primary screening was observed to have some susceptibility at a concentration of $62.5 \mu \mathrm{g} / \mathrm{mL}$ to purified acylchloramphenicols, exhibiting growth inhibition of $15 \%, 72 \%, 36 \%$, and $40 \%$ for compounds 2, 3, 4, and 6, respectively. At this same concentration the synthetic analogue compound $\mathbf{1 0}$ showed only marginal growth inhibition of $11 \%$, whereas compounds 17 and 18 (see below) were observed to inhibit S. aureus EAMC30 growth by $35 \%$ and $59 \%$, respectively. Interestingly, compounds 2, 4, and 10 showed activities in an initial testing against Mycobacterium intracellulare comparable to $\mathrm{Cm}$. Considering that the three active compounds were 3-acyl- or 1,3-diacylchloramphenicols, additional 1-acetylchloramphenicols were prepared for SAR studies. Thus, protection of the C-3 primary hydroxy group of $\mathbf{1}$ with TBSCl using imidazole as a base in dichloromethane gave compound 13. Acylation of 13 with acyl chloride using pyridine as a base in dichloromethane afforded compound 14, which was deprotected with $p$ toluenesulfonic acid in $\mathrm{H}_{2} \mathrm{O}-\mathrm{THF}(1: 4)$ to furnish the final products 1-acetylchloramphenicol (15), 1-propanoylchloramphenicol (16), 1-cinnamoylchloramphenicol (17), and 1-p-nitrobenzoylchloramphenicol (18) (Scheme 2; see detailed synthetic procedures in the Supporting Information).

Scheme 2. Synthesis of 1-Acylchloramphenicols 15-18

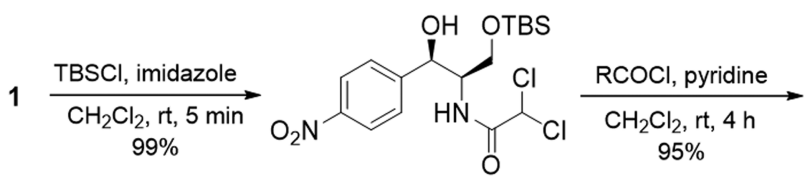

13

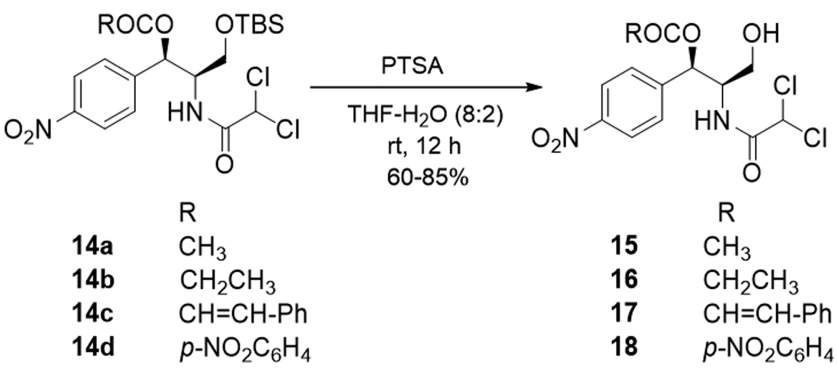




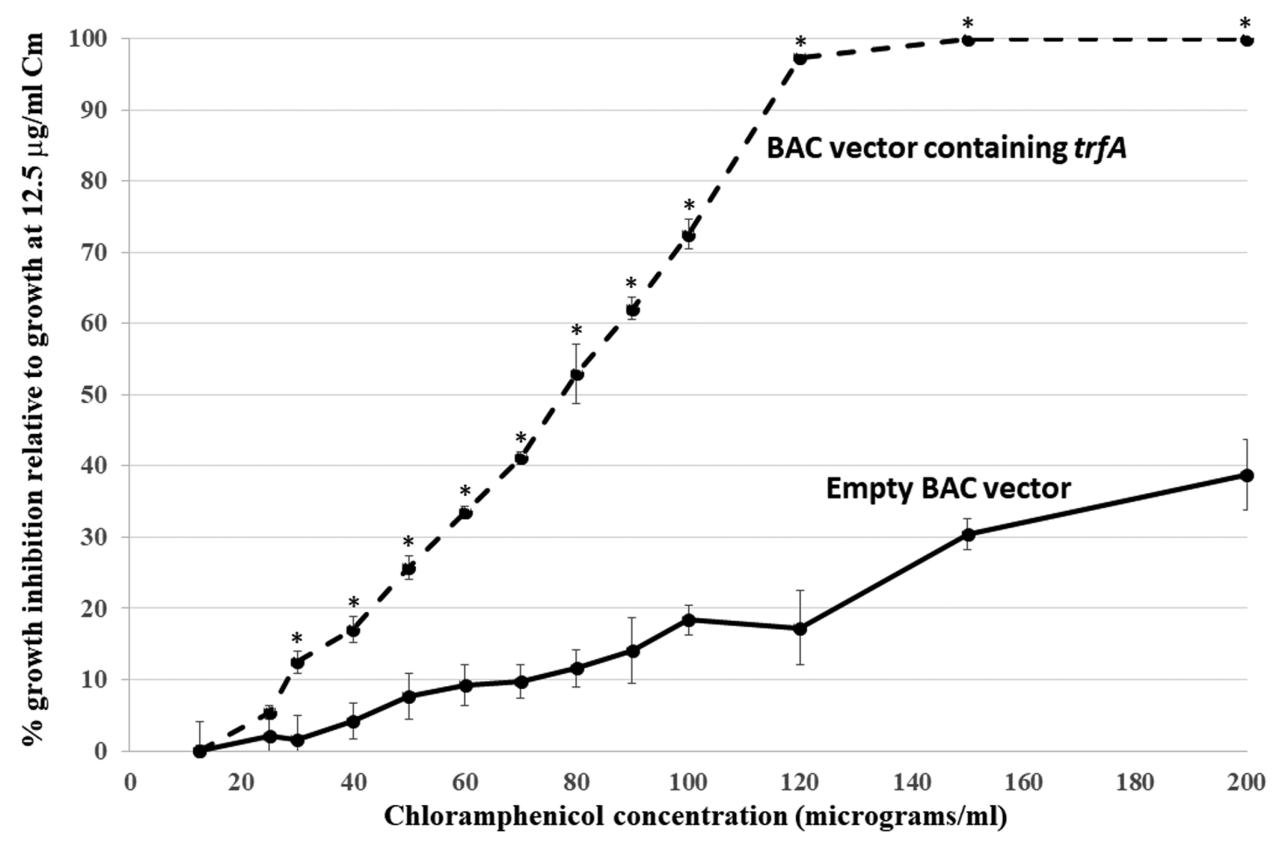

Figure 3. Growth inhibition of E. coli expressing trfA-containing clones at high Cm concentrations. The trfA gene was cloned into pSmartBAC-S vector and transformed into E. coli strain DH10B (dashed line) and compared to the pSmartBAC-S empty vector (solid line). The growth of each culture in the presence of $\mathrm{Cm}$ concentrations ranging from 12.5 to $200 \mu \mathrm{g} / \mathrm{mL}$ was determined by the optical density at $600 \mathrm{~nm}$ and expressed as the percent growth relative to growth at the standard $12.5 \mu \mathrm{g} / \mathrm{mL} \mathrm{Cm}$ added to the E. coli pSmartBAC-S culture for plasmid maintenance. Cultures in which there was a statstically significant increase $(P<0.05)$ in the percent inhibition of the culture containing trfA relative to the empty vector at the same $\mathrm{Cm}$ concentration are marked with an asterisk.

Compounds 2-7, 10-12, and 15-18 were tested for in vitro anti-Mycobacterium activity against $M$. intracellulare and the tuberculosis-causing strain $M$. tuberculosis in comparison with the positive controls $C m$ (1), ciprofloxacin, streptomycin, amd rifampin. The data are shown in Table S2, indicating that these compounds possessed moderate or marginal activity compared to ciprofloxacin and streptomycin. However, compound 18, with an aromatic-containing acyl substituent, was more active than $\mathrm{Cm}$ (1), giving minimum inhibitory concentrations (MICs) of 12.5 and $50.0 \mu \mathrm{g} / \mathrm{mL}$ against $M$. intracellulare and $M$. tuberculosis, respectively, versus 25.0 and $>100 \mu \mathrm{g} / \mathrm{mL}$, respectively, for $\mathrm{Cm}$ (1). The limited SAR information indicated that monoacyl substitutions on either C-1 or C-3 hydroxy groups of the $\mathrm{Cm}$ skeleton did not affect the activity against $M$. intracellulare, as evident by the equivalent potency of 2 and 15 (MIC, $25.0 \mu \mathrm{g} / \mathrm{mL}$ ).

Characterization of the Gene Responsible for Antimicrobial Activity in Clones P6B5 and P35B14. Subclones of P6B5 and P35B14 with anti-MRSA activity were found to contain the trfA gene sequence derived from the BACoptimized E. coli host strain (catalog no. 60215-1, Lucigen Corp.). The TrfA replication protein together with the oriV replication origin is considered the minireplicon for RK2 plasmids. ${ }^{35}$ When ori $V$ is present on a plasmid and trfA is under control of an arabinose-inducible promoter, the addition of arabinose induces BAC copy number to approximately 50 copies per cell. ${ }^{26}$ To determine the effect of copy induction on antibacterial activity, the $\operatorname{trf} A$ gene from clone P6B5 was PCR amplified and ligated into pSmartBAC-S, and the resulting plasmid pSmartBAC-S:trfA was transformed into E. coli strain DH10B. We observed that E. coli expressing pSmartBAC-S: trfA was inhibited in its growth at the highest concentrations $(>30$ $\mu \mathrm{g} / \mathrm{mL}$ ) of $\mathrm{Cm}$ as compared to the empty vector control (Figure 3). This finding suggests that $\mathrm{Cm}$ derivatives produced in E. coli clones expressing $\operatorname{trf} A$ attenuated $E$. coli growth by an as-yet-undescribed mechanism.

These data therefore indicate that $\operatorname{tr} A$ was the single gene necessary for antibacterial activity against MRSA in these two metagenomic clones. TrfA is known to be responsible for replication initiation and copy number control for RK2 plasmids; ${ }^{36}$ therefore, having trfA present on the BAC vector results in greater levels of BAC copy induction, and this is hypothesized to impact the generation of $\mathrm{Cm}$ derivatives presumably through a gene dosage mechanism in which the plasmid-borne chloramphenicol acetyltransferase is expressed at higher levels. TrfA contains a single-stranded DNA binding domain that activates the origin of vegetative replication in diverse bacterial species. ${ }^{37}$ The increased susceptibility of E. coli to $C m$ in the presence of the cloned $\operatorname{trfA}$ suggests that TrfA levels are directly proportional to the formation of $\mathrm{Cm}$ derivatives. Further research will be required to understand the mechanism(s) by which increased TrfA levels result in $\mathrm{Cm}$ derivative formation.

Characterization of the Esterase Expressed by Clone P6L4 That Regenerates $\mathrm{Cm}$. Enzymatic reactivation of $\mathrm{Cm}$ by chloramphenicol acetate esterases that counteract the chloramphenicol acetyl transferase (CAT) activity has been reported previously. ${ }^{38-41}$ A similar mechanism is probably responsible for the activity of P6L4 since the inset sequence had multiple ORFs with esterases as the predicted gene product (Supplemental Data 1). Three different esterases were predicted, including an esterase, a carboxylesterase, and a metallophosphoesterase (ORFs 12, 35, and 77, respectively; GenBank accession MF620030.1). These predicted esterases had low homology with each other, with the esterase amino acid sequence showing $30 \%$ identity to the carboxylesterase and $38 \%$ to the metallophosphoesterase, whereas the carboxylesterase and metallophosphoesterase amino acid sequences had $31 \%$ 
identity. A multiple alignment of all three esterases and their nearest GenBank matches did not reveal any conserved amino acid positions, whereas separate multiple alignments of each esterase and its respective homologous amino acid sequences obtained from GenBank did reveal conserved positions (Figures S3-S5, see Supporting Information). A phylogenetic analysis of each of these predicted esterases with a database of their nearest respective GenBank matches revealed that the predicted esterase and metallophosphoesterase were in clades well supported by bootstrapping and were affiliated with esterases originating from members of the phylum Chloroflexi, whereas there was poor bootstrap support for the clade that contained the predicted carboxylesterase (Figures S6-S8, see Supporting Information).

The esterase activity expressed by clone P6L4 was determined by adding a fluorescent BODIPY FL $\mathrm{Cm}$ substrate (BCAM) to the cultures. TLC results (Figure 4) indicated that

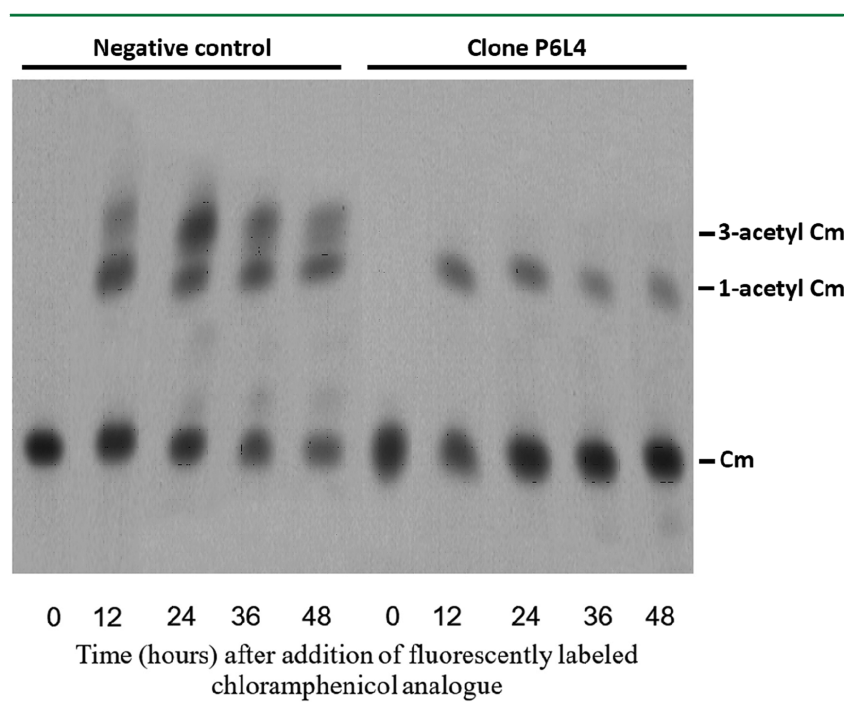

Figure 4. Comparison of negative control and clone P6L4 culture extract with BCAM as a substrate. Aliquots withdrawn every $12 \mathrm{~h}$ were processed for extraction with ethyl acetate and analyzed by TLC. Lanes were normalized for direct comparison of the negative control with P6L4.

the concentration of BCAM in the negative control decreased $\left(T_{0}-T_{48}\right)$ and that of the acetylated forms increased over time. Two different acetylated forms of BCAM (1-acetyl $\mathrm{Cm}$ and 3acetyl $\mathrm{Cm}$ ) were observed in the negative control, whereas only 1-acetyl $\mathrm{Cm}$ was seen in the presence of clone P6L4. ${ }^{42} \mathrm{~A}$ reverse trend was seen in clone P6L4, wherein the BCAM concentration increased and the acetylated form decreased over time, suggesting reactivation of $\mathrm{Cm}$ by esterase activity. The genes encoding three different predicted esterases in P6L4 were subcloned to investigate this and ascertain the role of these enzymes in $\mathrm{Cm}$ reactivation.

The carboxylesterase- and esterase-encoding genes, respectively, were successfully amplified using gene-specific primer sets, while the putative metallophosphoesterase gene failed to amplify under these same conditions despite multiple attempts. Further validation of the successful cloning and expression of the esterases was seen from the results of SDS-PAGE analysis (Figure S9). For the esterase and the carboxylesterase the use of rhamnose-inducible expression showed a greater concentration of the protein at an approximate molecular mass predicted for each respective esterase as compared to that of the uninduced sample.

The role of the esterases in the activity of clone P6L4 was evaluated by testing the subclones in a bioassay against the MRSA strain EAMC30. Transformation of the subclones (or the empty vector control) with pGNS-BAC enabled growth in LB broth containing $\mathrm{Cm}$. Inhibition of MRSA growth was observed for the esterase subclone but not for the carboxylesterase. The inhibition of MRSA growth was much higher when rhamnose was added to induce expression (Figure $5)$, as expected. These results suggest that the putative esterase

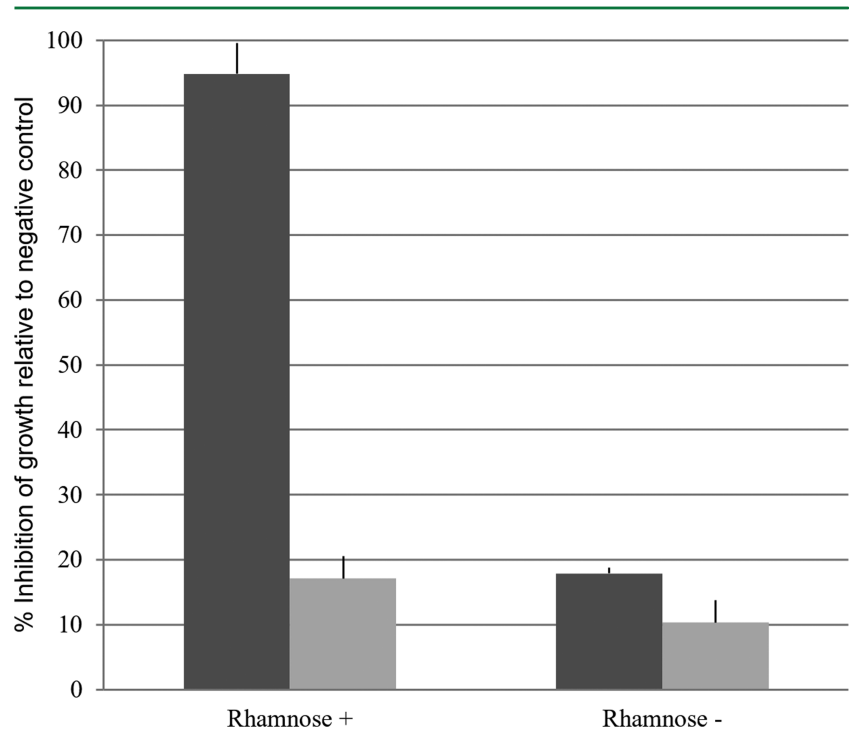

Figure 5. Comparison of anti-MRSA activity of the P6L4 subclones pRham-esterase (dark bars) and pRham-carboxylesterase (light bars) in the presence and absence of rhamnose-induced expression. The graph represents the \% growth inhibition of MRSA strain EAMC 30 by the subclones relative to the empty vector negative control, considered to have no inhibitory effect and calculated by measuring the fluorescence of reduced resazurin.

(clone P6L4, ORF 12) is at least partially responsible for the restoration of nonacetylated $\mathrm{Cm}$ responsible for the anti-MRSA activity observed in clone P6L4 supernatants. This esterase activity counteracts the mechanism encoded by the cat gene, thereby resulting in active $\mathrm{Cm}$ that was capable of inhibiting MRSA growth. This result is similar to that obtained from a functional metagenomic screen that resulted in the isolation of an esterase that reactivated chloramphenicol. ${ }^{43}$

In conclusion, chemical analysis of the metabolites expressed from metagenomic clones with anti-MRSA activities identified multiple $\mathrm{Cm}$ modifications. The supernatants of $E$. coli hosting these clones contained multiple $\mathrm{Cm}$ derivatives, three of which are novel $\mathrm{Cm}$ derivatives. The mechanism by which these $\mathrm{Cm}$ derivatives are synthesized is believed to be by enzymatic acylation of the $\mathrm{Cm}$ skeleton. This is supported by the data obtained from these metagenomic clones, indicating that expression of metagenomic-encoded enzymes (i.e., esterases) or a cloned gene that induced BAC vector copy number (i.e., $\operatorname{trfA}$ ) resulted in modification of the exogenously supplied $\mathrm{Cm}$ to produce these novel $\mathrm{Cm}$ derivatives. This methodology could be applied to other natural product scaffolds to generate novel derivatives of other chemical entities with biological activity. 
The progress made in these studies toward generation of large-insert metagenomic libraries in shuttle BAC vectors will be applied in the future for generation of larger-scale libraries that can encompass a greater diversity of soil microbial metagenomes and be expressed in multiple heterologous hosts. In particular, the use of other heterologous hosts engineered for expression of polyketide synthases as well as other biosynthetic gene clusters will take further advantage of these libraries for natural product discovery.

\section{EXPERIMENTAL SECTION}

General Experimental Procedures. Specific rotations were measured on an Autopol IV polarimeter at room temperature. ${ }^{1} \mathrm{H}$ and ${ }^{13} \mathrm{C}$ NMR spectra were recorded on a Bruker DRX NMR spectrometer operating at $400\left({ }^{1} \mathrm{H}\right)$ and $100\left({ }^{13} \mathrm{C}\right) \mathrm{MHz}$. Chemical shifts are expressed in ppm relative to the solvent residue signals. $2 \mathrm{D}$ NMR spectra (gradient DQF-COSY, HMQC, gradient HMBC, and NOESY) were run using standard Bruker pulse programs. Highresolution ESIMS data were obtained on an Agilent Series 1100 SL mass spectrometer. Column chromatography $(\mathrm{CC})$ was performed on silica gel $\left(40 \mu \mathrm{m}, \mathrm{J}\right.$. T. Baker) and reversed-phase silica gel $\left(\mathrm{C}_{18}, 40\right.$ $\mu \mathrm{m}$, J. T. Baker). Silica gel 60 F254 TLC plates (Merck, Darmstadt, Germany) and reversed-phase TLC plates $\left(\mathrm{C}_{18}\right.$, Merck, Darmstadt, Germany) were used for analytical TLC. LC-MS was run on an Agilent 1290 Infinity series chromatograph with a dual pump, autosampler, thermostated column compartment, and a diode array detector. The chromatograph was coupled with an Agilent 6120 single quadruple mass spectrometer with a dual APCI/ESI source operated in both the positive and negative modes. The system was controlled by ChemStation software. A Waters Acquity UPLC BEH C ${ }_{18}$ column (2.1 $\times 150 \mathrm{~mm}, 1.7 \mu \mathrm{m})$ was used. The experiments were carried out at a gradient elution from $10 \%$ to $100 \% \mathrm{CH}_{3} \mathrm{CN}$ in $\mathrm{H}_{2} \mathrm{O}$ in $20 \mathrm{~min}$ and then held for $6 \mathrm{~min}$. The quadrupole mass analyzer was operated in the scan mode with the mass range from 100 to 1500 . The drying gas flow was $10 \mathrm{~L} / \mathrm{min}$ at $300{ }^{\circ} \mathrm{C}$, the nebulizer pressure was $35 \mathrm{psi}$, and the vaporizer temperature was $200{ }^{\circ} \mathrm{C}$. The capillary voltage used was $3 \mathrm{kV}$, the corona current was $10 \mu \mathrm{A}$, and the charging voltage was 4 $\mathrm{kV}$. The fragmentor was set to 120 .

Bacterial Strains and Plasmids. Metagenomic libraries were transformed into the BAC-optimized E. coli strain DH10B BAC Replicator V2.0 (Lucigen Corp., Middleton, WI, USA) that contains the arabinose-inducible $\mathrm{P}_{\mathrm{BAD}}$ :trfA in the chromosome to support copy induction of BAC vectors. A clinical isolate from the East Alabama Medical Center (EAMC) designated as MRSA strain EAMC30 was used as a tester strain for antimicrobial activity screens.

Metagenomic Library Construction. High molecular weight (HMW) metagenomic DNA was isolated from a Cullars Rotation (Auburn, AL, USA) soil plot that had not been amended with fertilizers for the past 100 years. ${ }^{44}$ The isolation and purification of soil HMW DNA was conducted by isolating soil microorganisms that were embedded in low melting point agarose, treated with proteinase $\mathrm{K}$, and washed extensively as in a previously published protocol. ${ }^{45}$ The agarose was melted and the DNA was sheared by pipetting up to five times to generate DNA in the $>150 \mathrm{~Kb}$ range based on pulsed field gel electrophoresis. The agar was allowed to solidify again, and the DNA was end-repaired with the DNATerminator kit (Lucigen) in a total volume of $500 \mu \mathrm{L}$ with $10 \mu \mathrm{L}$ of enzymes and then heat killed at $70{ }^{\circ} \mathrm{C}$ for $15 \mathrm{~min}$. The end-repaired DNA was ligated with BstXI adaptors (10 $\mu \mathrm{L}$ of $100 \mu \mathrm{M}$ each) in a total volume of $700 \mu \mathrm{L}$ consisting of ligation reaction containing $10 \mu \mathrm{L}$ of ligase $(2 \mathrm{U} / \mu \mathrm{L}$, Epicenter $)$, followed by gel fractionation of large DNA fragments ranging from 100 to $200 \mathrm{~Kb}$ purified by pulse-field gel electrophoresis. Purified large DNA fragments (about $100 \mu \mathrm{L}, 1-3 \mathrm{ng} / \mu \mathrm{L}$ ) were ligated into the cloning-ready BstXI shuttle vector pSmartBAC-S $\left(16^{\circ} \mathrm{C}\right.$ for $\sim 18 \mathrm{~h}$ ). The ligated DNA mixture was electroporated into competent $E$. coli cells (BAC-Optimized E. coli 10G Replicator Cells, Lucigen). Smallscale ligations and transformations ( $1 \mu \mathrm{L}$ of DNA per $20 \mu \mathrm{L}$ of cells) were used to judge the cloning efficiency. The insert sizes of about 50
BAC clones were determined to find conditions that contained the desired insert size. Once the suitability of the trial ligation reaction was confirmed, large-scale ligations and transformations were conducted to achieve 19200 clones for the BAC library $(50 \times 384$-well plates arrayed).

Construction of Shuttle BAC Cloning Vector pSmartBAC-S. Construction of a BAC vector that would enable conjugal transfer into other bacterial hosts and integration into the host chromosome followed a method to construct a similar shuttle BAC vector (pMDB14) reported by Martinez and colleagues. ${ }^{46}$ We first restriction digested pSmartBAC (EU101022.1) with ApaI, end-repaired the DNA to make it blunt, and dephosphorylated the digested pSmartBAC vector ends. A synthesized and blunt-ended gene cassette that contained the $\phi \mathrm{C} 31$ integrase (int), attachment site (attP), and aac3(IV) that encodes for apramycin resistance (4793 bp) was ligated to the linearized $\mathrm{pSmartBAC}-\mathrm{S}$, and apramycin-resistant transformants in E. coli $10 \mathrm{G}$ were selected. The other phenotype ( $\mathrm{Cm}$ resistance) and the ability of the pSmartBAC-S to integrate into the $\phi \mathrm{C} 31$ attachment site of Streptomyces coelicolor were also confirmed (data not shown). The primary difference between pSmartBAC-S and pMDB14 is that pSmartBAC-S contains the inducible high-copy replication origin oriV. Plasmid pSmartBAC-S has been deposited at Addgene (ID\# 107268), and this and all other plasmids used in this study are listed in Table S3.

Metagenomic Library Screening for Antimicrobial Activity. For high-throughput screening of the library, an in situ lysis method was developed. Using a pin replicator, the BAC library containing E. coli cells was inoculated into deep 96-well plates containing $1.0 \mathrm{~mL}$ of LB supplemented with $12.5 \mu \mathrm{g} / \mathrm{mL} \mathrm{Cm}$ for selection of the vector plus a final concentration of $0.01 \%$ arabinose, followed by incubation at 37 ${ }^{\circ} \mathrm{C}$ for $48 \mathrm{~h}$ while shaking at $200 \mathrm{rpm}$. The E. coli cells were lysed by freezing at $-80{ }^{\circ} \mathrm{C}$, followed by rapid thawing at $55^{\circ} \mathrm{C}$. Then $100 \mu \mathrm{L}$ of a 1:1000-diluted, log-phase MRSA strain EAMC30 culture in LB containing $30 \mu \mathrm{g} / \mathrm{mL}$ nalidixic acid was added to each well followed by incubation at $37^{\circ} \mathrm{C}$ for $24 \mathrm{~h}$. Finally, $165 \mu \mathrm{L}$ of the viability indicator resazurin $(0.02 \%$ solution $)$ was added to each well, and the plates were incubated at $37^{\circ} \mathrm{C}$ for $1 \mathrm{~h}$ until a color change from blue to pink was observed for the majority of wells. ${ }^{47,48}$

Validation of Recombinant Clones with Antimicrobial Activity. Each recombinant clone that inhibited the growth and/or viability of the tester strain was regrown from the library that was cryopreserved in 384-well plate format into a $2 \mathrm{~mL} \mathrm{LB}$ broth culture containing $12.5 \mu \mathrm{g} / \mathrm{mL} \mathrm{Cm}$, incubated overnight at $37{ }^{\circ} \mathrm{C}$, and a separate glycerol stock was stored at $-80{ }^{\circ} \mathrm{C}$. Each positive clone was then inoculated into replicate wells $(n=4)$ of a 96-well plate and grown as above to retest the clone for inhibitory activity. Every positive clone that demonstrated reproducible antibiotic activity was tested for its ability to inhibit MRSA growth by removal of E. coli cells by centrifugation and transfer of supernatants to another microtiter plate. Results for each positive clone were noted according to the degree and consistency of inhibitory activity observed. In the resazurin-based bioassays, fluorescence readings of reduced resazurin (resorufin) were recorded (530 nm excitation and $590 \mathrm{~nm}$ emission) and used for calculating the \% inhibition of MRSA growth relative to the empty vector negative control. These results were used to narrow down the list of positive clones to the top candidates for additional genetic and biochemical characterization.

Retransformation of Antibiotic-Producing Clones. The validated antibiotic-producing clones were grown in $3 \mathrm{~mL}$ of $\mathrm{LB}$ containing $\mathrm{Cm}$, and after $16 \mathrm{~h}$ at $37^{\circ} \mathrm{C}$ the BAC DNA was extracted using an alkaline lysis method. A restriction digestion of each BAC clone with $\mathrm{BamHI}$ or EcoRI was resolved by PFGE at $6 \mathrm{~V} / \mathrm{cm}, 1$ to 15 $\mathrm{s}$ switch time for $12 \mathrm{~h}$ at $15^{\circ} \mathrm{C}$. The insert size for each BAC clone was estimated by comparison with DNA size standards. BAC DNA was retransformed into a naïve $E$. coli strain and selected on LB containing $12.5 \mu \mathrm{g} / \mathrm{mL} \mathrm{Cm}$ for the presence of the plasmid. Transformation was done by electroporation ( $1 \mathrm{~mm}$ gap cuvette, $1.8 \mathrm{kV}, 600 \mathrm{ohms}, 10 \mu \mathrm{F}$ ) into commercially available electrocompetent BAC replicator V2.0 cells (Lucigen). Each retransformed clone was tested as described above for antibiotic activity. Only recombinant clones showing 
evidence of a metagenomic insert and consistent and retransformable antibiotic activity were selected for further studies.

Testing for the Effect of Arabinose Induction. The antimicrobial expressing clones were evaluated for their antibiotic activity when grown in the presence and absence of arabinose induction. These clones were grown in $\mathrm{LB}$ containing $12.5 \mu \mathrm{g} / \mathrm{mL} \mathrm{Cm}$ with and without a final concentration of $0.01 \%$ arabinose, and the antibacterial assay was conducted as described above. The fluorescent intensities were recorded, and the data were analyzed to determine whether the addition of arabinose to the growth medium affected antibiotic activity.

Preliminary Characterization of Active Clones. A total of 27 clones that were reproducibly found to express antimicrobial activity when their BAC clone DNA was used to retransform a naïve $E$. coli were selected for further testing to determine if the active compound(s) was extra- or intracellular. For each clone, $2 \mathrm{~mL}$ of LB broth containing $12.5 \mu \mathrm{g} / \mathrm{mL} \mathrm{Cm}$ and $0.01 \%$ arabinose was inoculated with an E. coli glycerol stock stored at $-80{ }^{\circ} \mathrm{C}$. The culture tubes were incubated at $37{ }^{\circ} \mathrm{C}$ for $48 \mathrm{~h}$ while shaking at $200 \mathrm{rpm}$. Cultures were then divided into two sets $(1 \mathrm{~mL}$ each), with one set subjected to a freeze-thaw process (freezing at $-80{ }^{\circ} \mathrm{C}$ followed by rapid thawing at $55{ }^{\circ} \mathrm{C}$ ) and the other set subjected to centrifugation at $10000 \mathrm{~g}$, and then the supernatant was passed through a $0.2 \mu \mathrm{m}$ filter to obtain cell-free supernatants. These samples were then tested in 96well microtiter plates with three replicates $(200 \mu \mathrm{L}$ in each well) for each clone and treatment. Appropriate negative controls (empty vector with no insert) were used in the bioassay, and $20 \mu \mathrm{L}$ of diluted $\log$ phase MRSA strain EAMC30 (approximately $5.0 \times 10^{7} \mathrm{CFU}$ ) was added to each well. The addition of $30 \mu \mathrm{g} / \mathrm{mL}$ nalidixic acid was used to inhibit any residual E. coli cells in the cell lysates from the set subjected to the freeze and thaw treatments. Plates were incubated at $37^{\circ} \mathrm{C}$ for $24 \mathrm{~h}$ while shaking at $200 \mathrm{rpm}$. After incubation, $30 \mu \mathrm{L}$ of a $0.02 \%(\mathrm{w} / \mathrm{v})$ resazurin solution was then added to each well, and plates were further incubated at $37^{\circ} \mathrm{C}$ for $4-5 \mathrm{~h}$ while shaking at 200 $\mathrm{rpm}$. Fluorescence readings were recorded using a microtiter plate reader (excitation at $530 \mathrm{~nm}$ and emission at $590 \mathrm{~nm}$ ), and the percent reduction of resazurin fluorescence for each clone was determined by comparison with the respective negative controls.

To evaluate the heat stability and molecular weight of the heterologously expressed antibiotic activity, cultures were inoculated for the same set of 27 clones and the negative controls as before. At the end of $48 \mathrm{~h}$, the cultures were processed using either the freezethaw or cell-free supernatant method. For two of the clones (P6B5 and P37O10) the freeze-thaw treatment was used, and all of the remaining cell-free supernatants were divided into three sets to test the heat stability and estimate the molecular weight of the active fractions. Antibiotic activity due to a heat-labile and/or proteinaceous product was tested by boiling the cell-free supernatant or the lysate for $10 \mathrm{~min}$. Tubes were cooled to room temperature, and a bioassay was set up as described above. To determine if the activity was due to a compound less than $3 \mathrm{kDa}$ in size, $1 \mathrm{~mL}$ of the sample was fractionated using a centrifugal filter (VWR) with a modified poly(ether sulfone) membrane with $3 \mathrm{kDa}$ MWCO. The spin time was $15 \mathrm{~min}$ at $14000 \mathrm{~g}$, and the concentrate (reconstituted with half-strength LB broth) and the filtrate were tested in the bioassay format as described before.

DNA Sequence Generation and Analysis. Each of the 27 bioactive clones was selected for complete insert sequencing using either 454 pyrosequencing (454 Life Sciences, Branford, CT, USA) or an Ion Torrent PGM (Life Technologies, Grand Island, NY, USA). BAC DNA was isolated from $100 \mathrm{~mL}$ cultures of each respective clone using an alkaline lysis method. ${ }^{48}$ The purified DNA was used to generate bar-coded shotgun subclone libraries that were sequenced at Lucigen (in the case of Ion Torrent PGM) or at EnGenCore at the Univeristy of South Carolina (Columbia, SC, USA) using a Genome Sequencer FLX system as per the manufacturer's instructions. The sequences were trimmed for quality using a $Q$ score of $>30$ and assembled into contiguous fragments (contigs) using the CLC genomics workbench (Cambridge, MA, USA) de novo assembler. The contig(s) that represented the complete (or nearly complete) clone insert DNA was exported in FASTA format. ORFs were identified using a GeneMark heuristic model for prediction of prokaryotic genes. ${ }^{49}$ The ORF sequences were compared against the GenBank nr/nt database using BLASTx to predict the function of putative gene products. Sequences for each BAC clone were deposited in GenBank under accession numbers MF620010 to MF620035 and MF797910 for clone P35B14.

Subcloning ORFs Responsible for Antibiosis Activity. Clones that produced a $\mathrm{Cm}$ derivative were characterized by subcloning to identify the $\mathrm{ORF}(\mathrm{s})$ responsible for producing the anti-MRSA compound. BAC DNA was isolated from $500 \mathrm{~mL}$ cultures of each clone according to methods described previously. ${ }^{48}$ Approximately 20 $\mu \mathrm{g}$ of BAC DNA from each clone was sheared using a g-TUBE (Covaris, MA, USA) to obtain fragmented DNA within the range of 4 to $8 \mathrm{~kb}$. Fragmented DNA was separated using gel electrophoresis, and DNA of the targeted size was excised for purification. The ends of the fragmented DNA obtained by shearing were repaired using a DNA Terminator kit (Lucigen). End-repaired DNA from each clone was ligated into the pSMART vector (Lucigen) and then electroporated into electrocompetent E. coli $10 \mathrm{G}$ cells containing pGNS-BAC to provide $\mathrm{Cm}$ resistance. ${ }^{49}$ Subclones were selected on LB agar supplemented with $200 \mu \mathrm{g} / \mathrm{mL}$ ampicillin and $12.5 \mu \mathrm{g} / \mathrm{mL} \mathrm{Cm}$. The transformants were picked robotically using a QPix2 (Molecular Devices, Sunnyvale, CA, USA) in 96-well plates and were grown overnight with shaking at $200 \mathrm{rpm}$ at $37^{\circ} \mathrm{C}$. All the cultures grown in shallow 96-well plates were transferred to deep-well plates, and their anti-MRSA activity was determined according to the method described above. Subclones with anti-MRSA activity were grown for plasmid extraction, and the $\operatorname{ORF}(\mathrm{s})$ contained within active subclones were identified by primer walking PCR (Table S4) followed by sequencing. The size of the inset within positive subclones was determined by PCR using vector-specific primers.

Clone P6L4 ORFs Responsible for Antibacterial Activity. To assess the acylation of $\mathrm{Cm}, 2 \mathrm{~mL}$ broth cultures (containing $\mathrm{Cm}$ and arabinose) of clone P6L4 and an empty vector negative control were grown at $37^{\circ} \mathrm{C}$ for $12 \mathrm{~h}$ at $200 \mathrm{rpm}$. A portion $(600 \mu \mathrm{L})$ of the culture was transferred to fresh medium $(6 \mathrm{~mL}$ of $\mathrm{LB}$ broth containing $0.01 \%$ arabinose), and $30 \mu \mathrm{L}$ of BODIPY FL $\mathrm{Cm}$ (FAST CAT kit, ThermoFisher Scientific, Waltham, MA, USA) was added to each tube. Tubes were covered with aluminum foil and incubated in the dark at $37{ }^{\circ} \mathrm{C}$ for $48 \mathrm{~h}$ at $200 \mathrm{rpm}$. A $1 \mathrm{~mL}$ aliquot was withdrawn every $12 \mathrm{~h}\left(T_{0}\right.$ until $\left.T_{48}\right)$ and extracted with an equal volume of ethyl acetate. The organic layer was transferred and stored in brown microcentrifuge tubes at $-20^{\circ} \mathrm{C}$. At the end of $48 \mathrm{~h}$ all of the extracts were dried in the Centrivap and resuspended in $15 \mu \mathrm{L}$ of ethyl acetate, and $5 \mu \mathrm{L}$ of each sample was spotted on a silica gel TLC plate. A chloroform and methanol mixture $(87: 13)$ was used as the mobile phase, and the plate was visualized under UV light.

Amplification, cloning, and expression of each putative esterase gene from clone P6L4 were conducted using the Expresso Rhamnose SUMO cloning and expression system (Lucigen). Custom primers were designed for amplification of the respective gene sequence encoding each of the three different predicted esterases (Table S4). The thermal cycler was preheated to $94{ }^{\circ} \mathrm{C}$, and the reactions were incubated at $94{ }^{\circ} \mathrm{C}$ for $2 \mathrm{~min}$. A total of 25 cycles were performed with denaturation at $94{ }^{\circ} \mathrm{C}$ for $15 \mathrm{~s}$, annealing at $55{ }^{\circ} \mathrm{C}$ for $15 \mathrm{~s}$, and extension at $72{ }^{\circ} \mathrm{C}$ for $1 \mathrm{~min}$, with a final extension step at $72{ }^{\circ} \mathrm{C}$ for $10 \mathrm{~min}$. A $10 \mu \mathrm{L}$ amount of the PCR product was loaded onto an agarose gel (SB gel run for $2 \mathrm{~h}$ at $165 \mathrm{~V}$ ) for analysis. The PCR amplicon was cloned into the pRham vector using E. coli DH10B chemically competent cells (Lucigen) as per the kit protocol. A $100 \mu \mathrm{L}$ amount of the transformed cells was plated on YT agar plates containing $30 \mu \mathrm{g} / \mathrm{mL}$ kanamycin (Kan), and plates were incubated overnight at $37{ }^{\circ} \mathrm{C}$. Transformants from each plate were grown in YT broth with Kan at $37^{\circ} \mathrm{C}$ for $16 \mathrm{~h}$ at $200 \mathrm{rpm}$ followed by extraction of plasmid DNA. PCR (design and conditions as before) was used to confirm the presence of the cloned insert by using two primer sets, the esterase-specific primers and the SUMO forward and pETite reverse primers specific to the vector. The PCR product was analyzed as before by agarose gel electrophoresis and purified by the Wizard PCR Clean-up System (Promega, Madison, WI, USA). The amplified and 
purified DNA was sequenced and compared with the original sequence using the CLC Genomics Workbench and also analyzed by BLASTx comparison with the GenBank nr/nt database. A standard induction protocol was used for protein expression followed by SDS-PAGE analysis. $^{50}$

The esterase subclones were selected for growth on LB agar containing $50 \mu \mathrm{g} / \mathrm{mL}$ kanamycin, but in order to evaluate their respective ability to modify $\mathrm{Cm}$, it was necessary to introduce an additional vector that confers $\mathrm{Cm}$ resistance. E. coli strains containing the esterase subclones were made competent and transformed by electroporation (using conditions as described previously) with the pGNS-BAC vector DNA. ${ }^{49}$ An aliquot $(100 \mu \mathrm{L})$ of the transformed cells was plated on YT agar plates containing $12.5 \mu \mathrm{g} / \mathrm{mL} \mathrm{Cm}$, and plates were incubated overnight at $37^{\circ} \mathrm{C}$. An appropriate negative control was also conducted by using an E. coli strain containing the empty pRham vector and processing it similarly for electroporation with the pGNS-BAC vector.

Each of the transformants was inoculated into $5 \mathrm{~mL}$ of LB broth containing $12.5 \mu \mathrm{g} / \mathrm{mL} \mathrm{Cm}, 30 \mu \mathrm{g} / \mathrm{mL} \mathrm{Kan}$, and $0.2 \%$ rhamnose, and additional inoculations were made into $5 \mathrm{~mL}$ of LB broth containing $12.5 \mu \mathrm{g} / \mathrm{mL} \mathrm{Cm}$ and $30 \mu \mathrm{g} / \mathrm{mL}$ Kan without any added rhamnose. Cultures were incubated at $37^{\circ} \mathrm{C}$ for $48 \mathrm{~h}$ at $200 \mathrm{rpm}$, and cell-free supernatants were collected followed by testing against MRSA strain EAMC30 using the 96-well microtiter plate bioassay as described above. Results for induced expression with and without the addition of rhamnose were compared for the inhibition of MRSA growth.

Fermentation of Metagenomic Clones. Fermentation was conducted using LB broth, $0.01 \%$ arabinose, and $12.5 \mu \mathrm{g} / \mathrm{mL}$ of $\mathrm{Cm}$ at $37^{\circ} \mathrm{C}$ for $48 \mathrm{~h}$ with shaking at $200 \mathrm{rpm}$. LB broth was prepared using $10 \mathrm{~g}$ of tryptone, $5 \mathrm{~g}$ of yeast extract, and $10 \mathrm{~g}$ of $\mathrm{NaCl}$. For each of the E. coli BAC clones expressing antimicrobial activity, $200 \mathrm{~mL}$ of culture broth was placed in a $1 \mathrm{~L}$ flask with shaking at $250 \mathrm{rpm}$. After $48 \mathrm{~h}$, the supernatant was separated by centrifugation for $15 \mathrm{~min}$ and extracted with EtOAc. A one-liter culture was prepared for clones P35B14, P22E10, P28I7, P37I0, P27M10, P6B5, and P5A4, and the resultant EtOAc extracts were used for LC-MS analysis. For scale-up of fermentation of clone P35B14, a total of $40 \mathrm{~L}$ of culture was prepared to yield $1.614 \mathrm{~g}$ of EtOAc extract for follow-up isolation work.

Isolation of Chloramphenicol Derivatives from Clone P35B14. The EtOAc (1.35 g) extract was adsorbed over $4.0 \mathrm{~g}$ of normal-phase silica gel and loaded on a column using $120 \mathrm{~g}$ of normalphase silica gel. The column was eluted with a gradient solvent system consisting of acetone in hexanes (0-100\%) to afford 15 combined fractions $\left(\mathrm{F}_{1}-\mathrm{F}_{15}\right)$. Fraction $\mathrm{F}_{3}(135 \mathrm{mg})$ was chromatographed on reversed-phase silica gel $\mathrm{C}_{18}$ using $75 \% \mathrm{MeOH}$ in $\mathrm{H}_{2} \mathrm{O}$ to obtain subfractions $A_{1}-A_{7}$. Fractions $A_{3}(8.5 \mathrm{mg})$ and $A_{4}(3.5 \mathrm{mg})$ were combined and purified by normal-phase silica gel column chromatography using $30 \%$ acetone in hexanes to afford fractions $B_{1}-B_{12}$. Fractions $\mathrm{B}_{3}, \mathrm{~B}_{5}$, and $\mathrm{B}_{7}$ were identified as pure compounds 9 (0.9 $\mathrm{mg}), 6(2.5 \mathrm{mg})$, and $8(2.5 \mathrm{mg})$, respectively. Purification of fraction $\mathrm{F}_{4}(184.2 \mathrm{mg})$ on reversed-phase silica gel $\mathrm{C}_{18}$ with $75 \% \mathrm{MeOH}$ in $\mathrm{H}_{2} \mathrm{O}$ yielded 64 fractions. Similar fractions were combined based on TLC to give compounds 1 (20.0 mg), 2 (20.0 mg), 3 (8.2 mg), 4 (6.0 $\mathrm{mg}), 5(1.2 \mathrm{mg})$, and $7(1.1 \mathrm{mg})$.

3-Acetylchloramphenicol (2): white solid; $[\alpha]^{25}+29.4$ (c 0.5 , $\mathrm{EtOH}) ;{ }^{1} \mathrm{H}$ and ${ }^{13} \mathrm{C}$ NMR data matching reported values in the literature; ${ }^{29}$ HRESIMS $m / z$ 363.0149/365.0119 $[\mathrm{M}-\mathrm{H}]^{-}$(calcd for $\left[\mathrm{C}_{13} \mathrm{H}_{14} \mathrm{~N}_{2} \mathrm{Cl}_{2} \mathrm{O}_{6}-\mathrm{H}\right]^{-}$, 363.0156/365.0127).

3-Propanoylchloramphenicol (3): colorless liquid; $[\alpha]_{\mathrm{D}}^{25}+34.5(c$ $0.5, \mathrm{EtOH}) ;{ }^{1} \mathrm{H}$ and ${ }^{13} \mathrm{C}$ NMR data matching reported values in the literature ${ }^{29}$ HRESIMS $m / z$ 401.0276/403.0245 $[\mathrm{M}+\mathrm{Na}]^{+}$(calcd for $\left.\left[\mathrm{C}_{14} \mathrm{H}_{16} \mathrm{~N}_{2} \mathrm{Cl}_{2} \mathrm{O}_{6}+\mathrm{Na}\right]^{+}, 401.0278 / 403.0248\right)$.

3-Butanoylchloramphenicol (4): colorless liquid; $[\alpha]^{25}+25.4(c$ $0.45, \mathrm{EtOH}) ;{ }^{1} \mathrm{H}$ and ${ }^{13} \mathrm{C}$ NMR matching reported values in the literature; ${ }^{29}$ HRESIMS $m / z$ 415.0428/417.0396 $[\mathrm{M}+\mathrm{Na}]^{+}$(calcd for $\left.\left[\mathrm{C}_{15} \mathrm{H}_{18} \mathrm{~N}_{2} \mathrm{Cl}_{2} \mathrm{O}_{6}+\mathrm{Na}\right]^{+}, 415.0434 / 417.0405\right)$.

1,3-Diacetylchloramphenicol (5): colorless liquid; $[\alpha]_{D}^{25}-9.4(c$ $0.16, \mathrm{EtOH}) ;{ }^{1} \mathrm{H}$ and ${ }^{13} \mathrm{C}$ NMR matching reported values in the literature; ${ }^{29}$ HRESIMS $m / z$ 405.0259/407.0231 $[\mathrm{M}-\mathrm{H}]^{-}$(calcd for $\left[\mathrm{C}_{15} \mathrm{H}_{16} \mathrm{~N}_{2} \mathrm{Cl}_{2} \mathrm{O}_{7}-\mathrm{H}\right]^{-}$, 405.0262/407.0232).
1,3-Dipropanoylchloramphenicol (6): colorless liquid; $[\alpha]_{D}^{25}-6.3$ (c 0.7, DCM); ${ }^{1} \mathrm{H}$ and ${ }^{13} \mathrm{C}$ NMR data matching reported values in the literature; ${ }^{29}$ HRESIMS $m / z$ 433.0567/435.0543 $[\mathrm{M}-\mathrm{H}]^{-}$(calcd for $\left[\mathrm{C}_{17} \mathrm{H}_{20} \mathrm{~N}_{2} \mathrm{Cl}_{2} \mathrm{O}_{7}-\mathrm{H}\right]^{-}$, 433.0575/435.0545).

1-Acetyl-3-propanoylchloramphenicol (7): colorless liquid; $[\alpha]^{25}$ -4.9 (c 0.1, EtOH); ${ }^{1} \mathrm{H}$ and ${ }^{13} \mathrm{C}$ NMR data, see Table 1; HRESIMS $m / z 419.0413 / 421.0389[\mathrm{M}-\mathrm{H}]^{-}\left(\right.$calcd for $\left[\mathrm{C}_{16} \mathrm{H}_{18} \mathrm{~N}_{2} \mathrm{Cl}_{2} \mathrm{O}_{7}-\right.$ $\left.\mathrm{H}]^{-}, 419.0418 / 421.0389\right)$.

1-Acetyl-3-butanoylchloramphenicol (8): colorless liquid; $[\alpha]^{25}$ -8.9 (c 0.1, EtOH); ${ }^{1} \mathrm{H}$ and ${ }^{13} \mathrm{C}$ NMR data, see Table 1; HRESIMS $m / z 433.0570 / 435.0541[\mathrm{M}-\mathrm{H}]^{-}\left(\right.$calcd for $\left[\mathrm{C}_{17} \mathrm{H}_{20} \mathrm{~N}_{2} \mathrm{Cl}_{2} \mathrm{O}_{7}-\right.$ $\left.\mathrm{H}]^{-}, 433.0575 / 435.0545\right)$.

1-Propanoyl-3-butanoylchloramphenicol (9): colorless liquid; $[\alpha]^{25}{ }_{\mathrm{D}}-10.9(c 0.5, \mathrm{EtOH}) ;{ }^{1} \mathrm{H}$ NMR data, see Table 1; HRESIMS $m / z 447.0735 / 449.0714[\mathrm{M}-\mathrm{H}]^{-}\left(\right.$calcd for $\left[\mathrm{C}_{18} \mathrm{H}_{22} \mathrm{~N}_{2} \mathrm{Cl}_{2} \mathrm{O}_{7}-\right.$ $\mathrm{H}]^{-}, 447.0731 / 449.0702$ ).

Synthesis of 3-Acylchloramphenicols 3 and 4 and 1,3Diacylchloramphenicols 6 and 10. To a solution of $1(100 \mathrm{mg})$ in dry DCM $(5 \mathrm{~mL})$ were added pyridine $(0.03 \mathrm{~mL}, 1.1$ equiv) and dimethylaminopyridine (DMAP) ( $3.7 \mathrm{mg}, 0.1$ equiv) with a $2 \mathrm{~min}$ interval. After stirring for $5 \mathrm{~min}$, acyl chloride (butanoyl chloride or propionic anhydride, 1.1 equiv) was added. The reaction was monitored by TLC and stopped in 5 min. Removal of solvents from the reaction mixture by evaporation afforded a residue, which was chromatographed on silica gel using 30\% hexanes in EtOAc to yield monoacylated Cms 3 and 4 (85\%) and 1,3-diacylchloramphenicols 6 and $10(15 \%)$. The ${ }^{1} \mathrm{H}$ NMR data of synthetic 3, 4, and 6 were identical to those of the isolated compounds.

1,3-Dibutanoylchloramphenicol (10): colorless liquid; $[\alpha]_{\mathrm{D}}^{25}-6.6$ (c 0.58, EtOH); ${ }^{1} \mathrm{H}$ NMR $\left(\mathrm{CDCl}_{3}, 400 \mathrm{MHz}\right) \delta 8.23(2 \mathrm{H}, \mathrm{d}, J=9.4$ $\mathrm{Hz}), 7.53(2 \mathrm{H}, \mathrm{d}, J=8.6 \mathrm{~Hz}), 6.86(1 \mathrm{H}, \mathrm{d}, J=9.4 \mathrm{~Hz}, \mathrm{NH}), 6.08(1 \mathrm{H}$, $\mathrm{d}, J=5.5 \mathrm{~Hz}, \mathrm{H}-1), 5.89\left(1 \mathrm{H}, \mathrm{s}, \mathrm{CHCl}_{2}\right), 4.64(1 \mathrm{H}, \mathrm{m}, \mathrm{H}-2), 4.20(1 \mathrm{H}$, dd, $J=11.7,5.5 \mathrm{~Hz}, \mathrm{H}-3 \mathrm{a}$ ), 4.06 (1H, dd, $J=11.7,6.3 \mathrm{~Hz}, \mathrm{H}-3 \mathrm{~b}), 2.42$ $(2 \mathrm{H}, \mathrm{t}, J=7.8 \mathrm{~Hz}), 2.34(2 \mathrm{H}, \mathrm{t}, J=7.8 \mathrm{~Hz}), 1.65(4 \mathrm{H}, \mathrm{m}), 0.95(6 \mathrm{H}$, $\mathrm{dt}, J=3.1,7.1 \mathrm{~Hz}) ;{ }^{13} \mathrm{C}$ NMR $\left(\mathrm{CDCl}_{3}, 100 \mathrm{MHz}\right) \delta 173.2,172.3$, 164.2, 148.1, 143.6, 127.6, 124.1, 72.6, 66.1, 62.0, 52.9, 35.9, 35.8, 18.4, 18.3, 13.7, 13.6; HRESIMS $m / z$ 461.0902/463.0886 [M - H] $]^{-}$(calcd for $\left.\left[\mathrm{C}_{19} \mathrm{H}_{24} \mathrm{~N}_{2} \mathrm{Cl}_{2} \mathrm{O}_{7}-\mathrm{H}\right]^{-}, 461.0888 / 463.0858\right) ; 485.0841 / 487.0812$ $[\mathrm{M}+\mathrm{Na}]^{+}$(calcd for $\left.\left[\mathrm{C}_{19} \mathrm{H}_{24} \mathrm{~N}_{2} \mathrm{Cl}_{2} \mathrm{O}_{7}+\mathrm{Na}\right]^{+}, 485.0853 / 487.0823\right)$.

Synthesis of Regioisomers $\mathbf{1 1}$ and 12. To a solution of $\mathbf{3}$ or $\mathbf{4}$ $(40 \mathrm{mg})$ in dry dichloromethane (DCM) $(5 \mathrm{~mL})$ were added pyridine $(0.015 \mathrm{~mL}, 1.1$ equiv) and DMAP (0.1 equiv) sequentially with a 2 min interval. After stirring for $5 \mathrm{~min}$, propanoyl chloride or butanoyl chloride ( 1.1 equiv) was added. The reaction was monitored by TLC and continued for $15 \mathrm{~min}$. Removal of solvents from the reaction mixture by evaporation afforded a residue, which was chromatographed on silica gel using 30\% hexanes in EtOAc to yield 11 or 12 in a yield of approximately $95 \%$.

3-Butanoyl-1-propanoylchloramphenicol (11): colorless liquid; $[\alpha]_{\mathrm{D}}^{25}-10.9(c 0.5, \mathrm{EtOH}) ;{ }^{1} \mathrm{H}$ NMR data are identical to those of compound 9; ${ }^{13} \mathrm{C}$ NMR data, see Table 1; HRESIMS $m / z$ 447.0774/ $449.0746[\mathrm{M}-\mathrm{H}]^{-}\left(\right.$calcd for $\left[\mathrm{C}_{18} \mathrm{H}_{22} \mathrm{~N}_{2} \mathrm{Cl}_{2} \mathrm{O}_{7}-\mathrm{H}\right]^{-}, 447.0731 /$ 449.0702).

1-Butanoyl-3-propanoylchloramphenicol (12): colorless liquid; $[\alpha]^{25}-7.9$ (c 0.5, EtOH); ${ }^{1} \mathrm{H} \mathrm{NMR}\left(\mathrm{CDCl}_{3}, 400 \mathrm{MHz}\right) \delta 8.23(2 \mathrm{H}$, $\mathrm{d}, J=8.6 \mathrm{~Hz}), 7.54(2 \mathrm{H}, \mathrm{d}, J=8.6 \mathrm{~Hz}), 6.89(1 \mathrm{H}, \mathrm{d}, J=9.4 \mathrm{~Hz}, \mathrm{NH})$, $6.09(1 \mathrm{H}, \mathrm{d}, J=5.5 \mathrm{~Hz}, \mathrm{H}-1), 5.89\left(1 \mathrm{H}, \mathrm{s}, \mathrm{CHCl}_{2}\right), 4.64(1 \mathrm{H}, \mathrm{m}, \mathrm{H}-2)$, $4.20(1 \mathrm{H}, \mathrm{dd}, J=11.7,5.5 \mathrm{~Hz}, \mathrm{H}-3 \mathrm{a}), 4.09(1 \mathrm{H}, \mathrm{dd}, J=11.7,6.3 \mathrm{~Hz}$, $\mathrm{H}-3 \mathrm{~b}), 2.42(2 \mathrm{H}, \mathrm{t}, J=7.1 \mathrm{~Hz}), 2.36(2 \mathrm{H}$, pentet, $J=7.1 \mathrm{~Hz}), 1.67$ $(2 \mathrm{H}, \mathrm{m}), 1.15(3 \mathrm{H}, \mathrm{t}, J=7.8 \mathrm{~Hz}), 0.96(3 \mathrm{H}, \mathrm{m}) ;{ }^{13} \mathrm{C} \mathrm{NMR}\left(\mathrm{CDCl}_{3}\right.$, $100 \mathrm{MHz}) \delta 173.9,172.3,164.3,148.0,143.6,127.6,123.9,72.6,66.1$, 62.1, 52.9, 35.9, $27.318 .2,13.6,8.9$; HRESIMS $\mathrm{m} / \mathrm{z} 447.0813$ / 449.0787 (calcd for $\left[\mathrm{C}_{18} \mathrm{H}_{22} \mathrm{~N}_{2} \mathrm{Cl}_{2} \mathrm{O}_{7}-\mathrm{H}\right]^{-}, 447.0731 / 449.0702$ ).

In Vitro Antibacterial Assay. Organisms were obtained from the American Type Culture Collection (Manassas, VA, USA) and include methicillin-resistant $S$. aureus ATCC 1708, E. coli ATCC 2452, P. aeruginosa ATCC 2108, M. intracellulare ATCC 23068, and $M$. tuberculosis ATCC 25177. All organisms were tested using modified versions of the CLSI (formerly NCCLS) methods. ${ }^{51}$ Samples (dissolved in DMSO) were serially diluted in $20 \% \mathrm{DMSO} /$ saline 
and transferred $(10 \mu \mathrm{L})$ in duplicate to 96-well flat-bottom microplates. Inocula were prepared by correcting the $\mathrm{OD}_{630}$ of microbe suspensions in 5\% Alamar Blue (BioSource International, Camarillo, CA, USA) in Middlebrook 7H9 broth with OADC enrichment, $\mathrm{pH}=7.0$. Final sample test concentrations were 1/ 100th the DMSO stock concentration. Mycobacterium cultures were read at $544 \mathrm{ex} / 590 \mathrm{em}$ using the Polarstar Galaxy plate reader (BMG LabTechnologies, Germany) prior to and after incubation at $37{ }^{\circ} \mathrm{C}$ and $10 \% \mathrm{CO}_{2}$ for $70-74 \mathrm{~h}$ for $M$. intracellulare and 5 days for $M$. tuberculosis. $\mathrm{IC}_{50}$ values (concentrations that afford 50\% inhibition relative to controls) were calculated using XLfit 4.2 software (IDBS, Alameda, CA, USA) using fit model 201. The MIC is defined as the lowest test concentration that allows no detectable bacterial growth. Minimum bactericidal concentrations were determined by removing 5 $\mu \mathrm{L}$ from each clear (or blue) well, transferring to fresh media, and incubating as previously mentioned. The MBC is defined as the lowest test concentration that kills the organism (allows no growth).

\section{ASSOCIATED CONTENT}

\section{(5 Supporting Information}

The Supporting Information is available free of charge on the ACS Publications website at DOI: 10.1021/acs.jnatprod.7b00903.

Tables indicating the anti-MRSA activity of metagenomics clones, antibacterial activity of $\mathrm{Cm}$ derivatives, and the plasmids and oligonucleotides used in this study; synthetic procedures for compounds 15-18; NMR and MS spectra of compounds 1-18; multiple alignments of cloned and GenBank-obtained esterases, and phylogenetic analysis of each esterase (PDF)

Excel file (XLSX)

\section{AUTHOR INFORMATION}

\section{Corresponding Authors}

*(X.-C. Li) Tel: 662-915-6742. Fax: 662-915-7989. E-mail: xcli7@olemiss.edu.

*(M. R. Liles) Tel: 334-844-1656. Fax: 334-844-1645. E-mail: lilesma@auburn.edu.

\section{ORCID}

Mei Wang: 0000-0003-3686-4292

Mark R. Liles: 0000-0002-9313-8150

\section{Author Contributions}

${ }^{\#}$ S. Nasrin and S. Ganji contributed to this work equally and should be considered as cofirst authors.

\section{Notes}

The authors declare the following competing financial interest(s): M.R.L. and D.A.M. are cofounders of the Varigen Biosciences Corporation, which has financial interests in the metagenomic library.

\section{ACKNOWLEDGMENTS}

This work was supported by the National Institutes of Health NIAID (\#2R44AI085840-02 and \#5R44AI085840-03) and the USDA Agricultural Research Service Specific Cooperative Agreement No. 58-6408-2-0009. The authors wish to thank Ms. N. Capps and M. Wright for biological testing, Dr. B. Avula for recording high-resolution ESIMS spectra, R. Ye for technical help with library construction, and S. Jasinovica, M. Warner, and A. Kerowicz for technical help with next-generation sequencing.

\section{REFERENCES}

(1) Levy, S. B.; Marshall, B. Nat. Med. 2004, 10, S122-S119.
(2) Fischbach, M. A.; Walsh, C. T. Science 2009, 325, 1089-1093.

(3) Archer, N. K.; Mazaitis, M. J.; Costerton, J. W.; Leid, J. G.; Powers, M. E.; Shirtliff, M. E. Virulence 2011, 2, 445-59.

(4) Howden, B. P.; Davies, J. K.; Johnson, P. D.; Stinear, T. P.; Grayson, M. L. Clin. Microbiol. Rev. 2010, 23, 99-139.

(5) Lodise, T. P.; Graves, J.; Evans, A.; Graffunder, E.; Helmecke, M.; Lomaestro, B. M.; Stellrecht, K. Antimicrob. Agents Chemother. 2008, 52, 3315-3320.

(6) Soriano, A.; Marco, F.; Martinez, J. A.; Pisos, E.; Almela, M.; Dimova, V. P.; Alamo, D.; Ortega, M.; Lopez, J.; Mensa, J. Clin. Infect. Dis. 2008, 46, 193-200.

(7) Micek, S. T. Clin. Infect. Dis. 2007, 15, S184-S190.

(8) Liu, C.; Bayer, A.; Cosgrove, S. E.; Daum, R. S.; Fridkin, S. K.; Gorwitz, R. J.; Kaplan, S. L.; Karchmer, A. W.; Levine, D. P.; Murray, B. E.; M, J. R.; Talan, D. A.; Chambers, H. F. Clin. Infect. Dis. 2011, 52, 285-292.

(9) Tatarkiewicz, J.; Staniszewska, A.; Bujalska-Zadrony, M. Arch. Med. Sci. 2016, 12, 1327-1336.

(10) Handelsman, J.; Rondon, M. R.; Brady, S. F.; Clardy, J.; Goodman, R. M. Chem. Biol. 1998, 5, R245-R249.

(11) Iqbal, H. A.; Craig, J. W.; Brady, S. F. FEMS Microbiol. Lett. 2014, 354, 19-26.

(12) Hover, B. M.; Kim, S. H.; Katz, M.; Charlop-Powers, Z.; Owen, J. G.; Ternei, M. A.; Maniko, J.; Estrela, A. B.; Molina, H.; Park, S.; Perlin, D. S.; Brady, S. F. Nature Microbiol. 2018, 3, 1.

(13) Santana-Pereira, A. L. R.; Liles, M. R. In Functional Metagenomics: Tools and Applications; Charles, T. C.; Liles, M. R.; Sessitch, A., Eds.; Springer: Cham, Switzerland, 2017; pp 119-138.

(14) Rondon, M. R.; August, P. R.; Bettermann, A. D.; Brady, S. F.; Grossman, T. H.; Liles, M. R.; Loiacono, K. A.; Lynch, B. A.; MacNeil, I. A.; Minor, C.; Tiong, C. L.; Gilman, M.; Osburne, M. S.; Clardy, J.; Handelsman, J.; Goodman, R. M. Appl. Environ. Microbiol. 2000, 66, 2541-2547.

(15) Felczykowska, A.; Dydecka, A.; Bohdanowicz, M. L. G.; Gasior, T.; Sobon, M.; Kobos, J.; Bloch, S.; Nejman-Falenczyk, B.; Wegrzyn, G. Microb. Cell Fact. 2014, 13, 105.

(16) Gillespie, D. E.; Brady, S. F.; Bettermann, A. D.; Cianciotto, N. P.; Liles, M. R.; Rondon, M. R.; Clardy, J.; Goodman, R. M.; Handelsman, J. Appl. Environ. Microbiol. 2002, 68, 4301-4306.

(17) Wang, X.; Liu, Q.; Wang, H.; Luo, C. X.; Wang, G.; Luo, M. BMC Genomics 2013, 14, 1471-2164.

(18) Brady, S. F.; Chao, C. J.; Clardy, J. Appl. Environ. Microbiol. 2004, 70, 6865-6870.

(19) Banik, J. J.; Brady, S. F. Curr. Opin. Microbiol. 2010, 13, 603609.

(20) Rine, J.; Hansen, W.; Hardeman, E.; Davis, R. W. Proc. Natl. Acad. Sci. U. S. A. 1983, 80, 6750-6754.

(21) Strobel, R. J.; Sullivan, G. R. Manual of Industrial Microbiology and Biotechnology, 2nd ed.; ASM Press: UK, 1999.

(22) Nystrom, T. Mol. Microbiol. 2004, 54, 855-862.

(23) Wild, J.; Hradecna, Z.; Szybalski, W. Genome Res. 2002, 12, 1434-1444.

(24) Willison, J. C.; Magnin, J. P.; Vignais, P. M. Arch. Microbiol. 1987, 147, 134-142.

(25) Schoner, T. A.; Fuchs, S. W.; Schonau, C.; Bode, H. B. Microb. Biotechnol. 2014, 7, 232-241.

(26) Achenbach, H.; Kohl, W.; Reichenbach, H. Chem. Ber. 1976, $109,2490-2502$.

(27) Elkersh, T. A.; Plourde, J. R. J. Antibiot. 1976, 29, 292-302.

(28) Argoudel, A. D.; Coats, J. H. J. Antibiot. 1971, 24, 206-208.

(29) Gross, F.; Lewis, E. A.; Piraee, M.; van Pee, K. H.; Vining, L. C.; White, R. L. Bioorg. Med. Chem. Lett. 2002, 12, 283-286.

(30) Zhang, W.; Huffman, J.; Li, S. Y.; Shen, Y. M.; Du, L. C. BMC Biotechnol. 2017, 17, 59.

(31) Ottolina, G.; Carrea, G.; Riva, S. J. Org. Chem. 1990, 55, 23662369.

(32) Nakagawa, Y.; Nitahara, Y.; Miyamura, S. Antimicrob. Agents Chemother. 1979, 16, 719-723. 
(33) Kutrzeba, L. M.; Li, X.-C.; Ding, Y.; Ferreira, D.; Zjawiony, J. K.

J. Nat. Prod. 2010, 73, 707-708.

(34) Suzuki, Y.; Okamoto, S. J. Biol. Chem. 1967, 242, 4722-4730.

(35) Fang, F. C.; Helinski, D. R. J. Bacteriol. 1991, 173, 5861-5868.

(36) Perri, S.; Helinski, D. R.; Toukdarian, A. J. Biol. Chem. 1991, 266, 12536-12543.

(37) Wegrzyn, K.; Fuentes-Perez, M. E.; Bury, K.; Rajewska, M.; Moreno-Herrero, F.; Konieczny, I. Nucleic Acids Res. 2014, 42, 78077818.

(38) Nakano, H.; Tomita, F.; Yamaguchi, K.; Nagashima, M.; Suzuki, T. Biotechnol. Bioeng. 1977, 19, 1009-18.

(39) Sohaskey, C. D.; Barbour, A. G. Antimicrob. Agents Chemother. 1999, 43, 655-660.

(40) Sohaskey, C. D.; Barbour, A. G. J. Bacteriol. 2000, 182, 19301934.

(41) Sohaskey, C. D. FEMS Microbiol. Lett. 2004, 240, 187-192.

(42) Young, S. L.; Barbera, L.; Kaynard, A. H.; Haugland, R. P.; Kang, H. C.; Brinkley, M.; Melner, M. H. Anal. Biochem. 1991, 197, 401407.

(43) Tao, W. X.; Lee, M. H.; Yoon, M. Y.; Kim, J. C.; Malhotra, S.; Wu, J.; Hwang, E. C.; Lee, S. W. J. Microbiol. Biotechnol. 2011, 21, 1203-1210.

(44) Mitchell, C. C.; Delaney, D. Beltwide Cotton Conferences 2012, $1335-1344$

(45) Liles, M. R.; Williamson, L. L.; Rodbumrer, J.; Torsvik, V.; Goodman, R. M.; Handelsman, J. Appl. Environ. Microbiol. 2008, 74, 3302-3305.

(46) Martinez, A.; Kolvek, S. J.; Yip, C. L.; Hopke, J.; Brown, K. A.; MacNeil, I. A.; Osburne, M. S. Appl. Environ. Microbiol. 2004, 70, $2452-2463$.

(47) Martin, A.; Camacho, M.; Portaels, F.; Palomino, J. C. Antimicrob. Agents Chemother. 2003, 47, 3616-3619.

(48) Drummond, A. J.; Waigh, R. D. Recent Res. Dev. Phytochem. 2000, 4, 143-152.

(49) Besemer, J.; Borodovsky, M. Nucleic Acids Res. 1999, 27, 39113920.

(50) Sambrook, J.; Russell, D. W. Molecular Cloning: A Laboratory Manual; Cold Spring Harbor Laboratory Press: Cold Spring Harbor, New York, NY, 2001; Vol. 1.

(51) National Committee on Clinical Laboratory Standards. Susceptibility testing of Mycobacteria, Nocardia, and other aerobic Actinomycetes. Approved Standard, M24-A, 2003, 23. 